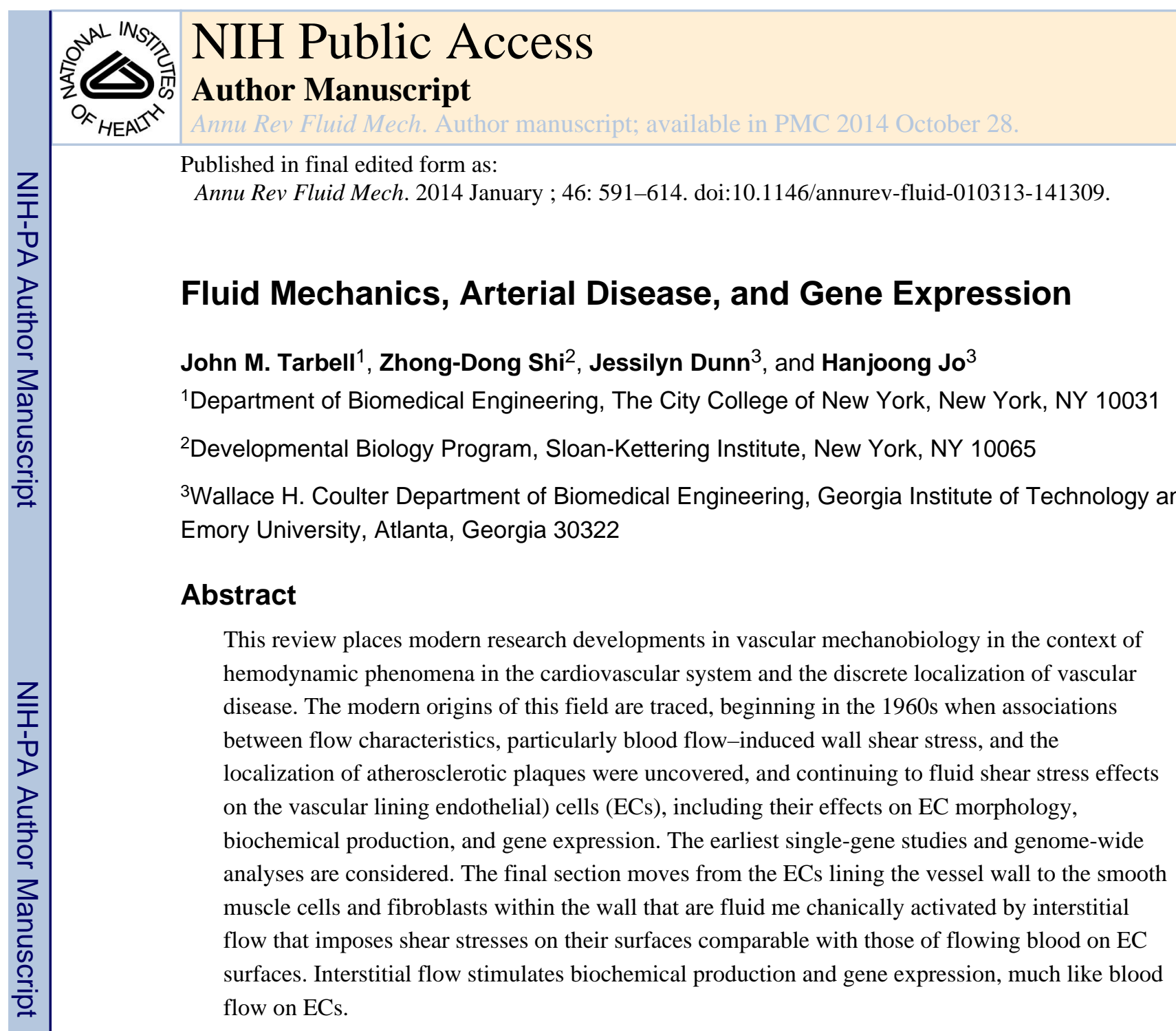

\title{
Keywords
}

shear stress; endothelial cells; smooth muscle cells; mechanotransduction; interstitial flow; glycocalyx

\section{INTRODUCTION AND OVERVIEW}

The physical scientist might view the cardiovascular system as an extremely efficient piping network composed of thousands of miles of pipe driven by a pump (the heart) that needs to deliver only a few watts of power to the circulating fluid. What distinguishes this system from purely physical pumping networks is of course that the pump, pipes, and fluid are composed of living cells that can survive only within limited ranges of mechanical forces imposed on them by the flow system. It is also remarkable that just a very small fraction of the total vessel length in the network is susceptible to diseases that threaten the function of

Copyright $@ 2014$ by Anuual Reviews. All rights reserved

hjo@bme.gatech.edu. tarbell@ecny.cuny.edu.

DISCLOSURE STATEMENT

The authors are not aware of any biases that might be perceived as affecting the objectivity of this review. 
the entire system. This review focuses particularly on the fluid mechanical characteristics of the cardiovascular system that are associated with vascular disease. As shown below, this focus has moved over time from correlations between fluid mechanical characteristics and vascular disease localization to considerations of underlying biological mechanisms and the associated mechanobiological coupling that leads to exquisite alterations of the component cells down to the level of gene expression networks. We hope to provide the reader with an appreciation of the milestones along the way, from early correlations to fundamental mechanisms, and to suggest areas for future research.

\section{ARTERIAL FLUID MECHANICS AND VASCULAR DISEASE}

\subsection{Vascular Fluid Mechanics}

The human cardiovascular system consists of a high-pressure systemic arterial network originating with the aorta and the left ventricle that services most of the body's tissues and a low-pressure pulmonary system originating with the pulmonary artery and the right ventricle that primarily supplies the lungs. Each of the arterial circuits proceeds through many branches, bifurcations, and curvatures to increasingly smaller vessels culminating in the microcirculation that provides the extended surface area for nutrient and waste exchange with the body's tissues and gas exchange in the lungs. Blood is returned to the heart through low-pressure systemic and pulmonary venous systems to complete the circuit. From a fluid mechanical point of view, the cardiovascular system presents a wide range of flow phenomena (Milnor 1989, Caro 2012). In the larger arteries and veins, which may be several centimeters in diameter with mean blood velocities of $20 \mathrm{~cm} / \mathrm{s}$ and peak velocities exceeding $100 \mathrm{~cm} / \mathrm{s}$ (resting conditions), The tube Reynolds number $(\mathrm{Re}=V D / v)$ can reach $10^{3}-10^{4}$, and inertial effects are dominant. Flow in the ascending aorta is often turbulent, and vortices are shed into the aorta from the leaflets of the aortic valve (Winter \& Nerem 1984, Ge et al. 2008). These inertially dominated flows lead to complex velocity profiles and the generation of secondary and separated flows in the curved, branched, and bifurcating structures of the large arteries (e.g., Vincent et al. 2011). The pulsatility of blood flow and pressure is also a prominent characteristic of the large arteries driven by the ventricular contractions, with peak systolic velocities exceeding $100 \mathrm{~cm} / \mathrm{s}$, returning nearly to 0 during diastole, and pressure varying between 120 and $80 \mathrm{~mm} \mathrm{Hg}$. The pulsing pressure in the large arteries induces cyclic stretching of the vessel wall (cyclic strain of order 5-10\%), which imparts solid mechanical strain and stress on the cells composing the wall. The unsteadiness or Womersley parameter $[a=(D / 2) \cdot \Downarrow(\omega / v)]$ of the flow in the aorta easily reaches 10 or more, and this combined with high Reynolds numbers and complex vessel geometries leads to a richness of inertially dominated flow phenomena that has been studied extensively (Friedman \& Ehrlich 1984, Ku et al. 1985, Tada \& Tarbell 2005) and still continues to attract new investigators as more advanced computational tools become available (Feintuch et al. 2007, Kim et al. 2010, Vasava et al. 2012).

As one moves through the arterial network, vessel sizes are ultimately reduced to the level of capillaries in the microcirculation (diameter of order $6 \mu \mathrm{m}$ ), the pressure drops from a mean of $100 \mathrm{~mm} \mathrm{Hg}$ down to $20 \mathrm{~mm} \mathrm{Hg}$, and the velocity and pulsatility are reduced to a point at which the flows are essentially inertia-less ( $\operatorname{Re} \ll 1$ and $\alpha \ll 1)$. The initial focus of 
this review is on phenomena in the larger arteries where vascular disease is most common and gene expression induced by Auid mechanical forces has been studied extensively.

\subsection{Arterial Wall Structure and Forces}

The arterial wall consists of three principal layers (Figure 1): the intima, media, and adventitia (Caro 2012). The endothelial cells (ECs) are in direct contact with blood, and they are acted upon by the normal and shearing forces of blood flow [pressure and wall shear stress (WSS)] as well as the circumferential stress (CS) induced by cyclic strain driven by the pressure pulse. All these forces (pressure, WSS, and CS) can induce gene expression in ECs, although the literature is dominated by studies of the effect of WSS on gene expression. The medial layer provides the arterial wall with the mechanical strength that is required to support the blood pressure-induced CS. The higher pressures in the large arteries are supported by thicker-walled vessels with multiple layers of smooth muscle cells (SMCs) that play a key role in the development of atherosclerosis and vascular disease. Gene expression in SMCs induced by cyclic stretch has been the subject of extensive research as well (Jeong et al. 2005, Li \& Xu 2007). Fibroblasts are also exposed to cyclic stretch, and there have been limited studies of gene expression induced in fibroblasts by CS (Uhl et al. 2011). ECs, SMCs, and fibroblasts are exposed to forces associated with the interstitial flow driven across the vessel wall by the difference in pressure between the blood vessel lumen and the external tissue pressure (close to $0 \mathrm{~mm} \mathrm{Hg}$ ). These interstitial flow forces induce biomolecular responses in vascular cells as well as in cancer cells (see Section 4 for details).

\subsection{Atherosclerosis}

Atherosclerosis is a disease of the arterial wall, and thrombotic events caused by it are by far the most common cause of death in the world (Domanski et al. 2011). Atherosclerosis is a complex disease (Figure 2) that involves the initial accunmlation of blood-borne lipids (e.g., LDL) in the intima followed by an immune response involving leukocyte (monocyte) binding from the bloodstream to the endothelium and transmigration to the intima where they are transformed into macrophages that scavenge lipids and enlarge into foam cells. Growth factors (mitogens) released by these intimal macrophages attract SMCs from the media into the intima where they also become enlarged with lipids to form foam cells that create a lesion in the vessel wall (Faxon et al. 2004). Early signs of these lesions may be present in the aortas of teenagers in the form of fatty streaks. Mature lesions develop with age and may form an occlusive plaque-blocking blood flow to downstream tissue or a nonocclusive plaque that is vulnerable to rupture and subsequent occlusive thrombus formation (Finn et al. 2010, Maldonado et al. 2012). Atherosclerosis does not arise uniformly on arterial surfaces throughout the vasculature but tends to be localized to specific sites such as branches and curvatures in which fluid mechanical factors deviate from their normal patterns in straight vessels. Gene expression patterns also differ at these arterial locations, suggesting a role for altered gene expression in the localization of disease (see Section 3). 


\subsection{Fluid Mechanics and the Localization of Atherosclerosis}

The role of fluid mechanics in atherosclerosis has its modern origins with work in the early 1960s suggesting that flow separation at sites of curvature, branching, or cross-sectional expansion might be linked to the development of atherosclerosis (McDonald 1960, Fox \& Hugh 1966). Fry (1969) showed that acutely increased shear stress altered the morphology and orientation of ECs, increased transendothelial transport of proteins, and athigher levels (above $380 \mathrm{dyn} / \mathrm{cm}^{2}$ ) led to overtendothelial damage. Although this study suggested the possibility that regions of high shear stress around artcrial branch would be sites or disease localization, studies by Caro and colleagues (Caro et al. 1969, 1971; reviewed in Caro 2009) in human cadavers showed that early lesions around the arterial branches of the abdominal aorta occurred upstream of the flow dividers where WSS was expected to be relatively low. The low-WSS hypothesis of atherosclerosis was subsequently supported by numerous studies. Friedman et al. (1981) introduced the idea of using casts of human arterial branches (the abdominal aortic bifurcation) to measure the WSS distribution in realistic pulsatile flow using laser Doppler velocimetry and simultaneously measuring intimal and medial thicknesses at corresponding sites in the vessel from which the cast was made. They observed a distinct negative correlation between WSS and intimal thickening, suggesting low WSS as a localizing factor. Related studies in the carotid artterial bifurcation using laser Doppler velocimetry in casts showed a strong correlation between early plaque location and low time averaged WSS (Zarins et al. 1983, Ku et al. 1985). Ku et al. (1985) also noted that the WSS reversed its direction from downstream to upstream over a large segment of the pulsatile flow cycle. This fluid mechanical phenomenon was characterized by a new parameter termed the oscillacory shear index (OSI), which varies from 0 (no reversal over the cycle) to 0.5 (equal segments of forward and reverse WSS). There was a strong correlation between intimal thickening and OSI as well as mean WSS. The flow field in the carotid bifurcation (Figure 3) subsequently has been srudied by many to carefully characterize the hemolynamic WSS environment (Tada \& Tarbell 2005, Bijari et al. 2012). The notion that low mean WSS and high OSI (WSS reversal) are the dominant fluid mechanical localizing factors in atherogenesis dominates current thinking in the field (Davies 2009, Janiczek et al. 2011).

However, the high WSS-low WSS debate is still ongoing as recent studies have shown that early lesions around the intercostal artery branch points in the thoracic aorta of immature rabbits are distributed downstream of the branch points where the WSS is high and along the lateral margins and upstream of the branch points in mature animals (Bond et al. 2011) in which computational fluid dynamics studies accounting for changes in aortic anatomy with age suggest high WSS as well (Peiffer et al. 2012). Other studies finding that intimal thickness was not associated with WSS patterns in the right coronary artery (Joshi et al. 2004) allude to additional possible factors in the mechanical environment that contribute to the localization of atherosclerosis (see the sidebar The Stress Phase Angle).

\subsection{From the Localization of Atherosclerosis to Shear Stress Effects on Endo the helial Cells}

Among the first mechanisms proposed to relate WSS patterns to the localization of atherosclerosis was one in which the fluid (blood) phase resistance to the transport of lipids 
(LDL) or other atherogens (step 1 in Figure 2) was controlled by the local wall shear rate (Caro et al. 1971). A subsequent study by Caro \& Nerem (1973) in the perfused dog common carotid artery suggested that the uptake of lipids in arteries could not be correlated with fluid phase mass transport rates, leading to the conclusion that the direct effects of blood flow on the endothelium must be important. Such direct effects were demonstrated most graphically by the observation that ECs change their morphology to elongate and align in the direction of flow (Dewey et al. 1981, Nerem et al. 1981). Suhsequently, investigators began to examine how fluid shear stress on ECs might influence the production of physiologically important biochemicals by the cells (see the sidebar LDL Permeability and the Leaky Junction).

Frangos et al. (1985) and Grabowski et al. (1985) observed that shear stress applied to static cells in culture that had not been exposed to shear stress previously induced the rapid (within minutes) and sustained (over a period of hours) production of prostacyclin, an important antithrombotic, antiproliferative, vasodilatory agent. These studies were followed by observations that shear stress on static ECs induced the transient release of in tracellular calciwn $\left(\mathrm{Ca}^{2+}\right)$, an important intracellular signaling molecule (Mo et al. 1991, Shen et al. 1992), and the sustained release (over hours) of the antiproliferative vasodilator nitric oxide (Kuchan \& Frangos 1994, Korenaga et al. 1994). Concurrently, during the early 1990s, the effects of shear stress on the expression of individual genes came into focus.

\section{THE STRESS PHASE ANGLE}

An alternative mechanical factor that correlates with the localization of atherosclerosis in arteries was suggested by Qiu \& Tarbell (2000). They emphasized that ECs are exposed simultaneously to fluid WSS and solid CS (Figure 1) and that the temporal phase angle between these two stresses, the stress phase angle (SPA), could vary significantly in different regions of the circulation. Their simulations of coronary arteries, in which atherosclerosis is prominent, showed a highly out-of-phase SPA, unlike the aorta (inphase SPA). A subsequent simulation of a compliant carotid bifurcation showed that SPA approached $-180^{\circ}$ on the outer wall of the sinus region where atherosclerosis is localized and approached $0^{\circ}$ on the inner wall of the sinus that is generally spared of disease (Tada \& Tarbell 2005). Additional studies examined the effect of the SPA on gene expression in vitro (Dancu et al. 2004) and in vivo (Dancu \& Tarbell 2007), showing that out-ofphase SPA induced an atherogenic gene expression profile. Tada et al. (2007) examined the effect of the SPA on the strain energy density of the EC plasma membrane showing that mean satrain energy density was increased for out-of-phase SPA. Other recent studies have suggested the SPA as a factor in plaque development in the right coronary artery (Torii et al. 2009), the carotid artery (Makris et al. 2010), and arterial stenoses (Sadeghi et al. 2011).

\section{LDL PERMEABILITY AND THE LEAKY JUNCTION}

Although Caro \& Nerem (1973) did not observe a correlation between the wall shear rate and uptake of LDL in excised arteries perfused for a period of hours (acute experiments), alterations of shear stress in arteries for several days revealed that EC apoptosis 
(programmed cell death) and cell turnover (mitosis) increase significantly under lowshear stress conditions (Cho et al. 1997). Weinbaum et al. (1985) hypothesized that leaky junctions around cells in a state of apoptosis or mitosis provide the major pathway for transport of large molecules such as LDL across the endothelium. More recent studies have shown a strong correlation between apoptosis and mitosis rates and LDL permeability of endothelial monolayers in culture (Cancel \& Tarhell 2010, 2011). These studies, and others (reviewed in Tarbell 2003, 2010), suggest that chronic differences in shear stress do affect LDL transport into the vessel wall and that low shear stress may be expected to increase LDL permeability.

\section{FLUID MECHANICS AND GENE EXPRESSION}

\subsection{Induction of Single Genes}

Traditionally, gene expression studies conducted in vascular tissue were limited to singlegene analyses of mechanical responsiveness and functional roles in regulating cell shape and behavior with regard to vascular homeostasis and disease development (Sharefkin et al. 1991, Hsieh et al. 1992, Mitsumata et al. 1993). Model systems engineered to study the effect of fluid shear stress on ECs included shear-exerting bioreactors such as the cone and plate viscometer and parallel-plate perfusion flow chamber (Bussolari et al. 1982, Davies \& Tripathi 1993, Davies 1995) for in vitro studies and porcine, murine, and canine models for in vivo studies. Although bioreactor systems offered the advantage of precise control over flow conditions, fluid composition, and environmental conditions and allowed the freedom to study human cells, they lacked several important factors that exist in the in vivo setting, such as mechanical cell substrate interactions, cross talk with local and circulating cells and molecules, and variable rheologic properties.

In the early 1990s, the idea of single-gene analysis was advanced by the discovery of shear stress response elements (SSREs) or common cis-acting elements of gene promoters that are regulated by a single shear-controlled transcription factor. SSREs enable the coregulation of a host of genes under specific environmental conditions that activate their common transcription factor. Resnick et al. (1993) discovered the first SSRE common to the key signaling molecules PDGF- $\beta$ (platelet derived growth factor beta), tPA (tissue plasminogen activator), ICAM-1 (intercellular adhesion molecule 1), and TGF $\beta 1$ (transforming growth factor beta 1), which are all induced by laminar shear conditions. SSREs have also been identified in other key genes, such as VEGR (vascular endothelial growth factor receptor) and eNOS (endothelial nitric oxide synthase), and there are likely many SSREs that remain to be discovered (Abumiya et al. 2002, Davis et al. 2004).

\subsection{Genome-Wide Analysis}

With the advent of high-throughput genome-wide analysis technology such as the microarray, it became possible to study the expression of thousands of genes throughout the genome simultaneously (Schena et al. 1995). This greatly impacted the field of vascular mechanobiology by enabling researchers to track a large host of genes in a controlled, welldefined environment. The resulting studies displayed clear evidence of the ECs' keen ability to sense and convert mechanical stimuli into biochemial signaling responses. Microarray 
studies illuminated numerous key regulatory pathways and their dynamics while also supporting the discovery of novel mechanosensitive genes and functional gene dusters. These data sets continue to support the working hypothesis that laminar, unidircctional flow upregulates atheroprotective genes and downregulates atheropathogenic genes, whereas disturbed, reversing, or stagnant flows result in the opposite phenomenon of enhancing atheropathogenic genes and suppressing atheroprotective genes.

In 2001, the complementary DNA (cDNA) microarray was first utilized in vitro to study the effect of shear stress on gene expression profiles of cultured ECs. Gimbrone's group used the cDNA array to define gene expression profiles of 11,397 genes in cultured human umbilical vein ECs exposed to steady laminar flow, turbulent flow, or static flow over $24 \mathrm{~h}$. Functional tests determined that several mechanosensitive genes activated under laminar flow were in fact atheroprotective and that the reciprocal was true regarding atheropathogenic genes (García-Cardeña et al. 2001a,b). Cbien's lab discovered 125 differentially regulated mechanosensitive genes in human aortic ECs exposed to laminar flow versus static conditions by a less comprehensive cDNA microarray but under more rigorous statistical testing as compared to Gimhrone's (Chen et al. 2001). Both groups used reverse transcription polymerase chain reaction validation and array analyses described below in more detail. Broadly, it was found that gene expression profiles in ECs exposed to laminar, unidirectional flow are distinctly different from those under disturbed flow, whereas static flow profiles have a strong resemblance to turbulent shear expression profiles. More specifically, laminar shear stress causes the suppression of genes associated with inflammatory responses, matrix remodeling, and cell proliferation and activates genes involved in signal transduction, cytoskeletal remodeling, and angiogenesis.

Because in vitro environments cannot fully recapitulate the effects of shear stress on the vascular endothelium in vivo, microarray studies evolved to in vivo settings to reveal the pathophysiological relevance of gene expression profiles in the vascular endothelium exposed to specific flow conditions. Although there has been probrressin the characterization of endogenous flow profiles in vivo (He et al. 2008), the necessity for more detailed studies of gene function in vivo brought about the development of the mouse partial carotid ligation model by Nam et al. (2009). In this model, disturbed flow is induced in the left common carotid artery by ligation while the right common carotid artery remains untouched as an internal control. The same group developed a novel endothelial messenger RNA (mRNA) and microRNA collection technique that enabled the use of microarray technology to study global gene expression changes in mouse endothdium exposed to disturbed flow in an in vivo setting. The data set generated findings of 523 mechanosensitive genes changed within 2 days of disturbed flow exposure, including numerous genes previously undescribed in the context of the cardiovascular system ( $\mathrm{Ni}$ et al. 2010a).

There are various approaches to microarray data analysis. Raw data can be analyzed in the most straightforward manner by comparison of the relative intensities of probe hybridization, expressed as a fold change, which represent the levels of differential transcript expression. Rigorous statistical analysis and filtering are necessary to lend significance to fold change values. Large data sets can be parsed by hierarchical clustering based on various criteria such as gene ontology, location in the genome, and expression 
patterns alluding to coregulation. However, this method may disregard underlying trends and often cannot tease out complex biological interactions formed by specialized gene circuitry. Gimbrone's group created the analytical software Argus, which allows the integration of multiple experimental conditions to help account for this difficulty. Both open source and proprietary system biological tools such as Ingenuity Pathways Analysis have become available. Inaddition to systems-wide analyses, computational tools at the genespecific level such as DAVID, amiGO, NCBI UniGene, and the UCSC Genome Browser make gene ontology and functional studies quite feasible.

\subsection{Mechanosensitive Signaling Pathways}

As a result of these studies, numerous key mechanosensitive genes have been discovered and studied in great detail based on their role in EC homeostasis and disease development (Chien 2007). Specific intracellular signaling pathways that become prevalent under low/ oscillatory, atheroprone shear stress are juxtaposed with pathways that dominate under high, atheroprotective, laminar shear areas, cyclic stretch, and appropriate hydrostatic pressure (Figure 4) (Gimbrone et al. 2000). A host of mechanosensitive, atheroprotective genes that are highly expressed in laminar, unidirectional flow conditions has been uncovered. This includes eNOS, the gene responsible for nitric oxide production and maintenance of vascular tone, and several other genes involved in cell survival that have antithrombotic, antiinflammatory, and antioxidant properties such as the Kruppel-like factor family (namely KH2 and KH4), and superoxide dismutases (Mn-SOD, EC-SOD) (Topper et al. 1996). Additional mechanosensitive genes involved in immune response activation such as MCP-1 (Shyy et al. 1994, Hsiai et al. 2003), VCAM1, TCAM-1 (Nagel et al. 1994), NFk $\beta$ (Chappell et al. 1998, Hajra et al. 2000); reactive oxygen species production (NADPH oxidases); and extracellular matrix reorganization causingvascular remodeling (TIMP-3, MMP-1) are found to be proatherogenic with their expression suppressed under undirectional laminar flow conditions and overexpressed under deleterious disturbed flow conditions. Many mechanosensitive cell cycle regulators involved in EC homeostasis, including p53, GADD45, p21 (Lin et al. 2000), and ERK (Akimoto et al. 2000), play a key role in growth and proliferation suppression or activation.

One area of special interest lies in the discovery of master regulators that control a large network of genes. These biomolecules would serve as excellent therapeutic targets for disease studies. Potentially important master regulators include epigenetic modifiers and transcription factors that participate in pretranscriptional regulation, microRNAs involved in pretranslational regulation of protein expression, and post-translational modifiers such as kinases. Epigenetic modifications such as DNA methylation, histone modifications, and chromatin remodeling alter the genomic DNA structure and accessibility. Transcription factors are proteins recruited to specific regions of a gene promoter to form a transcriptional complex that assists RNA polymerase to bind and transcribe the gene to mRNA.

MicroRNAs have a complememary sequence to specific mRNAs and can block their translation or cause their degradation. Once the mRNA has been successfully translated into a protein, post-translational modifications control their activity and stability. For example, kinases can activate or deactivate a protein by phosphorylation, and the post-translational modifier ubiquitin may ubiquitinylate a protein to target it for destruction by the proteasome. 
Putative key microRNAs (miR21, miR712, and miR10a) (Fang et al. 2010) and epigenetic chromosome structural organizers (histone deacetylases, DNA-binding proteins) are currently the subject of extensive research to detennine their roles in large-scale gene network regulation.

\subsection{Mechanotransduction}

A subset of the mechanosensitive genes mentioned above has been found to be vital for the ECs' ability to sense mechanical stimuli (Figure 5). When their expression or normal activity is interrupted, cells do not undergo phenotypic or gene expression changes associated with a specific mechanical stimulus, for example, the transformation from a polygonal shape to an elongated shape aligned with the direction of flow under laminar shear stress conditions (White et al. 1983, Wong et al. 1983). The intact mechanosensory complex at EC junctions consisting of PECAM-1, VE-cadherin, and VEGFR2 is crucial for the EC to be able to activate antiatherosclerotic gene programs in response to laminar flow (Tzima et al. 2005). Several other important mechanotransduction pathways that begin at the glycocalyx (Florian et al. 2003, Weinbaum et al. 2007, Tarbell \& Ebong 2008, Zeng et al. 2012) and the cell membrane, including integrins (focal adhesion kinases), cell membrane proteins (receptor tyrosine kinases, $\mathrm{G}$ protein coupled receptors), ion channels $\left(\mathrm{Ca}^{2+}\right)$, and intercellular junctions, are propagated hiochemically through the cytosol or mechanically via the cytoskeleton to ultimately affect gene expression in the nucleus (Resnick et al 1993, Chien et al. 1998, Davies 2009, Schwartz 2010).

\section{INTERSTITIAL FLOW SHEAR STRESS REGUIATES GENE EXPRESSION INVASCUIAR SMOOTH MUSCLE CELLS}

As described in the preceding sections, a large volume of research in cardiovascular flud mechanics and vascular biology has focused on understanding the mechanobiology of shear stress io ECs. Vascular SMCs, naturally located in the medial layer of the arterial wall and not exposed to blood flow, did not receive much attention from the fluid mechanics community until 1995 when a theoretical study suggested that there is a significant level of shear stress on SMCs imposed by transmural interstitial flow (Wang \& Tarbell 1995). Since then, increasing evidence has shown that fluid shear stress can induce global genetic changes in SMCs. These genetic changes regulate SMC biology and function, including signaling molecule secretion, cytokine expression, phenotypic switching, proliferation, and migration (Shi \& Tarbell 2011).

\subsection{Vascular Smooth Muscle Cells in Vascular Remodeling and Disease}

The major functions of arterial SMCs are to fine-tune blood vessel tone, blood pressure, and blood flow distribution in the body by contraction and relaxation (Owens et al. 2004, Shi \& Tarbell 2011). A widely accepted dogma, although requiring further rigorous validation (Gomez \& Owens 2012, Tang et al. 2012, Nguyen et al. 2013), is that SMCs possess remarkable plasticity that allows profound and reversible changes in phenotype between a contractile state and a synthetic/proliferative state in response to alterations in microenvironmental cues and thus that SMCs play a crucial role in vascular repair and remodeling (Owens et al. 2004, Rensen et al. 2007). Under abnormal conditions, SMCs may 
contribute to vascular lesion formation, including neointima formation and atherosclerosis, by activation (dedifferentiation) and migration from the media to the intima in which they proliferate and synthesize the extracellular matrix (Dzau et al. 2002, Owens et al. 2004). In vivo work has shown that adventitial fibroblasts also contribute to neointima formation following vascular injury by activation (i.e., differentiation to myofibroblasts) and migration into the intima (Shi et al. 1996, Sartore et al. 2001, Stenmark et al. 2006).

\subsection{Smooth Muscle Cells Are Exposed to Elevated Fluid Flow and Shear Stress After Vascular Injury}

Vascular SMCs and fibrohlasts are siruated in a three-dimensional (3D) environment comprising extracellular matrix proteins and experience primarily the mechanical forces of pressure and cyclic stretch (Hishikawa et al. 1994, Haga et al. 2007, Li \& Xu 2007), as suggested in Figure 6. These cells are not normally exposed to the shear stresses of flowing blood in the vascular system because the endothelial layer prevents them from directly contacting the blood flow. However, in cases of endothelial damage (e.g., by vascular procedures such as angioplasty or at the anastomoses of vascular grafts), the superficial layer of SMCs may be exposed directly to blood flow shear stresses at similar levels that ECs experience in intact blood vessels (Figure 6a) (Shi \& Tarbell 2011).

A more subtle mechanism by which the medial SMCs and adventitial fibroblasts are exposed to fluid shear stress is through transmural interstitial flow driven by the transvascular pressure differential. The pressure in the arterial lumen is higher than the pressure in the surrounding tissue, resulting in an interstitial flow from the arterial lumen toward the adventitia (Shi \& Tarbell 2011). This transmural interstitial fluid flow is very small, with a superficial velocity of the order of $10^{-5}$ to $10^{-6} \mathrm{~cm} / \mathrm{s}$. Because these velocities are $10^{4}$ to $10^{8}$ times lower than mean blood flow velocities, their potential for imposing significant stresses on embedded cells was not recognized until Wang \& Tarbell (1995), using a Brinkman theory to describe interstitial flow around an embedded cell, developed a simple equation $\left[\tau_{w} \approx \mu u_{\infty} / \sqrt{\left(K_{p}\right)}\right]$ to estimate the interstitial flow shear stresses on SMCs, which surprisingly could be of order dynlcm $\sim 1 \mathrm{dyn} / \mathrm{cm}^{2}$.

More recently, studies have shown that SMCs, similar to ECs, have a surface glycocalyx layer that plays a role in sensing and transducing interstitial flow forces (Ainslie et al. 2005; Shi et al. 2010a, 2011; Shi \& Tarbell 2011). To account for the presence of a glycocalyx layer on suspended cell surfaces, Tarbell \& Shi (2013) developed a simple theoretical model that incorporates a cell surfac porous media layer (the glycocalyx) on a cell suspended in a semi-infinjre porous media (extracellular matrix) (Figure 6b). Using a Brinkman model for each porous media layer and a balance of forces to calculate the solid stress in the glycocalyx, they found surprisingly that solid stresses that are transmitted to tlic cell may be 10-100 times the fluid stresses on the surface-in the range of 5-60 dyn $/ \mathrm{cm}^{2}$ for reasonable parameters describing arterial walls and cancerous tumors (Tarbell \& Shi 2013). Fluid shear stress on the cell membrane is estimated by $\tau_{w} \approx \frac{\mu u_{\infty} \sqrt{K_{g}}}{K_{m}}$ and solid stress transmitted 
through the glycocalyx to the cell membrane is estimated by $\tau_{w g} \approx \frac{\mu u_{\infty} H}{K_{m}}$ (Tarbell \& Shi 2013). Based on these theories, transmural interstitial flow and shear stress on SMCs and fibroblasts are expected to be elevated after chemical or mechanical injury to the endothelium and inflanunation- or hypertension-induced enhancement of vascular hydraulic conductivity (Shou et al. 2006, Michel et al. 2007, Rizzo 2009).

\subsection{Fluid Flow Regulates Smooth Muscle Cell Cytokine Expression and Signaling Molecule Release}

Cytokincs and signaling molecules can be secreted by both ECs and SMCs and play critical roles in vessel function and disease. Similar to what has been demonstrated in ECs, shear stress can also stimulate SMCs to express or secrete these vasoactive mediators. Upregulation of these molecules in turn may modulate gene expression in SMCs. For exan1ple, 2D shear stress (3-25 dyn $\left./ \mathrm{cm}^{2}\right)$ that simulates me direct effect of blood flow on SMCs (Figure 6a) increases both PDGF and bFGF (basic fibroblast growth factor) release from SMCs (Sterpetti et al. 1993, 1994; Rhoads et al. 2000). The increased secretion of bFGF may mediate shear stress-induced gene expression and the activity of ACE (angiotensin converting enzyme) (Gosgnach et al. 2000a). Similarly, shear stress also increases ACE activity in vascular ECs and adventitial fibroblasts (Gosgnach et al. 2000a). Jn rwo dimensions, shear stress $\left(1 \mathrm{dyn} / \mathrm{cm}^{2}\right)$ can induce a significant augmentation of prostaglandin production (Alshihabi et al. 1996). Interstitial Gow can also induce prostaglandin production in SMCs in there dimensions with a much lower production rate man mat observed in two dimensions (Wang \& Tarbell 2000). High shear stress downregulates human PAR-1 (protease activated receptor-1) expression, and low shear stress upregulates it (Papadaki et al. 1998a), which is consistent with the known variations in human PAR-1 expression in vascular injury and atherosclerosis. In contrast, tPA expression increases in areas of high shear stress and decreases in areas of low shear stress, in which a thrombus is likely to form (Papadaki et al. 1998a). Shear stress can induce nitric oxide production via the upregulation of neuronal or inducible nitric oxide synthase (NOS) (Papadaki et al. 1998b, Gosgnach et al. 2000b), and nitric oxide may cross talk wim prostacyclin (Osanai et al. 2001). Contradicting these studies, Wagner et al. (1997) observed no upregulation of inducible NOS in response to a similar level of fluid shear stress. This discrepany likely resulted from differences in culturing aortic SMC (i.e., with or without serum starvation) right before applying shear stresses, which might affect the SMC phenotypic state and properties, almough the exact cause of the discrepancy is not clear. Furmermore, shear stress may activate SMC membrane ion channels, leading to an influx of second messengers such as $\mathrm{Ca}^{2+}$ and $\mathrm{Mg}^{2+}$ (Sharma et al. 2002, Oancca et al. 2006) and downstream gene expression. The ability of shear stress to regulate vasoactive mediators and signaling molecules in vascular SMCs indicates that the effects of interstitial fluid shear on SMCs may play important roles in maintaining vascular homeostasis and modulating vascular pathologies (Shi \& Tarbell 2011). 


\subsection{Fluid Flow Affects Gene Expression Modulating Smooth Muscle Cell Proliferation and Phenotype}

Once signaling molecules are activated by shear stress, downstream gene expression patterns change, which may lead to cell dedifferentiation, proliferation, and migration. In vitro 2D stud ies show that laminar shear stress reduces SMC proliferation (Sterpetti et al. 1993, Papadaki et al. 1996, Ekstrand et al. 2010, Jia et al. 2013), likely mediated by TGF $\beta$ signaling (Ucha et al. 1997). In vivo studies of vascular SMC growth rates after balloon catheter injury have demonstrated an inverse correlation between hrrowth rates and shear stress (Kohler \& Jawien 1992), supporting the in vitro observations. Laminar shear stress can also induce SMC apoptosis by inhibiting Aktactivity (Fitzgerald et al. 2008), increasing expression of tissue factor pathway inhibitor-2 (Ekstrand et al. 2010), or acting through an autocrine Fas/FasL pathway (Apenberg et al. 2003).

Other 2D studies, however, have shown that pulsatile or oscillatory shear stress can promote SMC proliferation (Haga et al. 2003, Asada et al. 2005, Hsu et al. 2011). The increased SMC proliferation is regulated by the shear stress-induced activation of Akt and ERK1/2 signaling pathways or the expression of cylin D1 (Haga et al. 2003, Asada et al. 2005, Hsu et al. 2011). A recent study revealed that steady shear stress can also induce the expression of transcription factor of early growth response-1 in SMCs, which is dependent on ERK1/2 and JNK signaling activation (Ni et al. 2010b).

Shear stress also modulates the vascular SMC phenotype by regulating phenotypic gene expression, which is most likely mediated by ERK1/2 signaling. It has been shown that shear stress induced in an orbital shaker reduces the expression of SMC contractile markers (a-actin and calponin) and stimulates the expression of synthetic phenotype markers (vimentin and 13-actin) (Asada et al. 2005). Other studies indicate that shear stress can decrease the levels of SMC markers (a-actin, calponin, SM-MHC, and SM22) (Wang et al. 2006, Shi et al. 2010a), while increasing the expression of EC markers (PECAM-1, vWF, and VE-cadherin) (Wang et al. 2006). Those studies suggest that shear stress might promote EC transdilforentiation from SMCs. More recently, Shi et al. (2010a) presented the first evidence that 3D interstitial flow also can modulate the expression of SMC phenotypic markers. This study showed that interstitial flow $(0.5 \mu \mathrm{m} / \mathrm{s} ; 4.5 \mathrm{~h})$ inhibits the expression of SM-MHC, smoothelin, and ealponin genes in 3D collagen, which is consistent with the effect of 2D shear stress ( $\left.8 \mathrm{dyn} / \mathrm{cm}^{2} ; 15 \mathrm{~h}\right)$. Interestingly, interstitial flow enhances the expression of a-actin and SM22 in both SMCs and myofibroblasts in three dimensions, opposite to what 2D laminar flow does (Shi et al. 2010a). The differential effects of 2D flow and 3D interstitial flow may result from different initial phenotypic states of SMCs, as SMCs cultured in 3D collagen display less spreading and proliferation and express lower levels of a-actin than those in two dimensions (Li et al. 2003, Stegemann et al. 2005, Rensen et al. 2007). Other scudjes show that the simultaneous exposure of pulsatile strain and shear stress can increase immature and dedifferentiated vascular SMC proliferation and a-actin expression in 3D polymer scaff olds (Jeong et al. 2005). Further more, mechanotransduction through heparan sulfate proteoglycan-mediated ERK1/2 activation may play a central role in modulating SMC phenotypes under both 2D flow and interstitial flow (Shi et al. 2010a). 


\subsection{Fluid Flow Affects Gene Expression Promoting Smooth Muscle Cell Migration}

The migration of vascular SMCs from the media plays a key role in neointima formation, atherosclerosis, and restenosis (Figure 2). SMCs have displayed reduced migratory activity in response to elevated blood flow in a balloon catheter injury model in vivo (Kohler \& Jawien 1992). Similarly, 2D shear stress $\left(12-15 \mathrm{dyn} / \mathrm{cm}^{2}\right)$ inhihics SMC migration in vitro via a reduction in PDGF rcceptor- $\beta$ and nitric oxide-mediated downregulation of matrix metalloproteinases (MMPs) (Palumbo et al. 2000, Garanich et al. 2005). Other studies, however, showed that 2D pulsatilc flow shear stress increases SMC migration in vitro (Hendrickson et al. 1999, Redmond et al. 2001). These results demonstrate that different types of flows may impact SMC function very differently. In addition, fibroblasts and myofibroblasts also respond to shear stress, showing an increased and decreased migration, respectively (Garanich et al. 2007). These results suggest that the cell phenotype may play a role in the response to shear stress stimulation.

To investigate interstitial flow influences on SMC motility, Shi and colleagues (2009, 2010b, 2011) established a 3D interstitial flow-cell migration assay using a modified Boyden chamber system. In these studies, the flow period (up to $6 \mathrm{~h}$ ) was separated from the migration period $(48 \mathrm{~h}$ ) to minimize possible flow-induced autologous chemotaxis effects on cell migration (Fleury et al. 2006; Shi et al. 2009, 2011). They provided the first evidence that interstitial flow upregulates gene expression and activity of rat interstitial collagenase (MMP-13) that promotes the migration of rat aortic SMCs, fibroblasts, and myofibrohlasts in collagen gels (Shi et al. 2009). However, high intensity interstitial flow induces the expression of tissue inhibitor of metalloproteinasc- 1 and cell death, resulting in a reduced motility (Shi et al. 2009). Flow-induced upregulation of MMP-13 is mediated by the activation of ERK1/2 and expression of the downstream transcriptioD factor c-Jun (Shi et al. 2010b). The interstitial flow mechanotransduction is controlled by the SMC surface glycocalyx heparan sulfate proteoglycans and focal adhesion kinase activation (Shi et al. 2011). Notably, this was the first study to describe a detailed flow-induced mechanotransduction mechanism in three dimensions, and thus it may shed light on our under-randing of interstitial flow-related mechanobiology in vascular disease and tumor metastasis and has implications in tissue engineering.

However, many inconsistent observations remain to be resolved and undersrood. Contradictory observations have been reported frequently in studies of SMCs exposed to shear stress in two dimensions. For instance, laminar shear stress can either inhibit or promote SMC proliferation. These disparate result probably resulted from variations in initial phenotypic states of the SMCs used in different studies. One can also clearly see that SMCs respond to fluid flow differently in two than in three dimensions. SMCs in vivo are exposed to interstitial flow in three dimensions and are not normally exposed to blood flow (2D), except in the case of endothelial denudation in which the first layer of SMCs might directly experience blood flow before it is coated with a fibrin layer. In addition, in migration studies, Matrigel, gelatin, and fibronectin have been used as me 2D substrate materials and typically collagen I as the 30 matrix, which only approximate the complex tissue matrix in vivo. Furthermore, in 30 systems, the distinct cell-matrix adhesions (Cukierman et al. 2001) and other elements such as matrix structure, surface glycocalyx, and 
tethering may be involved in interstitial flow mechanosensation and transduction (Pedersen et al. 2007, Shi et al. 2011, Tarbell \& Shi 2013).

\section{SUMMARY AND OUTLOOK}

Blood flow shear stress and interstitial flow shear stress can have pronounced effects on gene expression in vascular ECs and SMCs, resulting in a vast range of changes in their biology and function. This emerging field is rich with unresolved problems and future challenges for research. From a mechanical perspective, the determination of how solid mechanical forces (e.g., CS) modulate the influences of fluid mechanical forces (WSS) on EC gene expression is an underexplored area that will require detailed modeling studies of comhined fluid mechanics and solid mechanics in arteries as well as cellular gene expression studies in the presence of defined WSS and CS. For mechanobiology, much work is required to tease out the molecular event involved in mechanotransduction. This will be key to understanding how specific intracellular signaling pathways become activated/deactivated in response to flow patterns that are characterized by distinct mechanical signatures. Moreover, the determination of key master regulatory genes that control proinflammatory and prothrombotic pathways in the case of ECs, and promigratory and proproliferative pathways in the case of SMCs, will provide insight for novel therapeutic targets. Additionally, the study of interstitial flow effects on vascular cell biology is truly in its infancy. It is still necessary to develop SMC culture models that faithfully mimic the complex 3D in vivo environment and to develop in vivo models with controlled interstitial flow that will allow more realistic studies of SMC responses.

Clearly, the mechanotransduction mechanisms by which ECs and SMCs sense fluid flow in complex environments remain to be investigated in much greater detail. Fully understanding how fluid flow forces and other physical factors regulate EC and SMC biology and function will increase our understanding of vascular development and disease and promote the discovery of novel therapeutic strategies.

\section{Acknowledgments}

This work was supported by funding from National Institutes of Health grants to J.M.T (HL057093, HL086543, HL094889) and to H.J. (HL095070, HL70531, and HHSN268201000043C), a World Class University Project (R31-2008-000-10010-0) from the Ministry of Science, Technology, and Education of South Korea and John and Jan Portman Professorship (H.J.). J.D. is a National Science Foundation Predoctoral Fellow.

\section{Glossary}

Gene expression

Endothelial cells (ECs)

Wall shear stress (WSS) the process by which information fromn a gene is used in the synthesis of a functional gene product, often a protein

the monolayer of blood vessel-lining cells that resist blood clotting and provide parrier to regulate solute transport into the vessel wall

the tangential stress of flowing blood on a blood vessel's innersurface, usually the endothelial cell surface 


\author{
Circumferential stress \\ (CS) \\ SMC
}

Atherosclerosis
Oscillatory shear index
(OSI)
SSRE
cDNA

Mechanotransduction

Glycocalyx

Vascular smooth muscle
cell

Transmural interstitial

flow

MMP the stress in the circumferential direction of a blood vessel; it is borne by the solid components of the vessel wall

smooth muscle cell

a progressive arterial disease characterized by thickening of the intima (plaque) that may become occlusive or vulnerable to rupture

a measure of the fraction of a pulsatile flow cycle during which the WSS is in the upstream direction

shear stress response element

complementary DNA

refers to the many mechanisms by which cells convert mechanical stimuli (e.g., WSS) into chemical activity, including gene expression.

the layer of proteoglycans covering mammalian cells; glycosaminoglycan surfaces sense flow forces and transmit them through core proteins

the main cell in the medial layer of an artery that resists circumferental strees and manutes to the intma in atherosclerosis

flow through the interstitial spaces of the blood vessel wall, typically driven by the differential between blood pressure and tissue pressure

matrix metalloproteinase

\section{LITERATURE CITED}

Abumiya T, Sasaguri T, Taba Y, Miwa Y, Miyagi M. Shear stress induces expression of vascular endothelial growth factor receptor Flk-1/KDR through the CT-rich Sp1 binding site. Arterioscler. Thromb. Vasc. Biol. 2002; 22:907-13. [PubMed: 12067897]

Ainslie KM, Garanich JS, Dull RO, Tarbell JM. Vascular smooth muscle cell glycocalyx influences shear stress-mediated contractile response. J. Appl. Physiol. 2005; 98:242-49. [PubMed: 15322072]

Akimoto S, Mitsumata M, Sasaguri T, Yoshida Y. Laminar shear stress inhibits vascular endothelial cell proliferation by inducing cyclin-dependent kinase inhibitor $\mathrm{p} 21^{\text {Sdi1/Cip1/Waf1 }}$. Circ. Res. 2000; 86:185-90. [PubMed: 10666414]

Alshihabi SN, Chang YS, Frangos JA, Tarbell JM. Shear stress-induced release of $\mathrm{PGE}_{2}$ and $\mathrm{PGI}_{2}$ by vascular smooth muscle cells. Biochem. Biophys. Res. Commun. 1996; 224:808-14. [PubMed: 8713127]

Apenberg S, Freyberg MA, Friedl P. Shear stress induces apoptosis in vascular smooth muscle cells via an autocrine Fas/FasL pathway. Biochem. Biophys. Res. Commun. 2003; 310:355-59. [PubMed: 14521917]

Asada H, Paszkowiak J, Teso D, Alvi K, Thorisson A, et al. Sustained orbital shear stress stimulates smooth muscle cell proliferation via the extracellular signal-regulated protein kinase $1 / 2$ pathway. J. Vasc. Surg. 2005; 42:772-80. [PubMed: 16242567] 
Bijari PB, Antiga L, Wasserman BA, Steinman DA. Improved prediction of disturbed flow via hemodynamically-inspired geometric variables. J. Biomech. 2012; 45:1632-37. [PubMed: 22552156]

Bond AR, Iftikhar S, Bharath AA, Weinberg PD. Morphological evidence for a change in the pattern of aortic wall shear stress with age. Arterioscler. Thromb. Vasc. Biol. 2011; 31:543-50. [PubMed: 21205986]

Bussolari SR, Dewey CF Jr, Gimbrone MA Jr. Apparatus for subjecting living cells to fluid shear stress. Rev. Sci. Instrum. 1982; 53:1851-44. [PubMed: 7156852]

Cancel LM, Tarbell JM. The role of apoptosis in LDL transport through cultured endothelial cell monolayers. Atherosclerosis. 2010; 208:335-41. [PubMed: 19709659]

Cancel LM, Tarbell JM. The role of mitosis in LDL transport through cultured endothelial cell monolayers. Am. J. Physiol.Heart Circ. Physiol. 2011; 300:H769-76. [PubMed: 21169397]

Caro CG. Discovery of the role of wall shear in atherosclerosis. Arterioscler. Thromb. Vasc. Biol. 2009; 29:158-61. [PubMed: 19038849]

Caro, CG. The Mechanics of the Circulation. Cambridge Univ. Press; Cambridge, UK: 2012.

Caro CG, Fitz-Gerald JM, Schroter RC. Arterial wall shear and distribution of early atheroma in man. Nature. 1969; 223:1159-60. Introduces the low-WSS hypothesis for the localization of atherosclerosis. [PubMed: 5810692]

Caro CG, Fitz-Gerald JM, Schroter RC. Atheroma and arterial wall shear: observation, correlation and proposal of a shear dependent mass transfer mechanism for atherogenesis. Proc. R. Soc. Lond. B. 1971; 177:109-59. [PubMed: 4396262]

Caro CG, Nerem RM. Transport of ${ }^{14} \mathrm{C}$-4-cholesterol between serum and wall in the perfused dog common carotid artery. Circ. Res. 1973; 32:187-205. [PubMed: 4685963]

Chappell DC, Varner SE, Nerem RM, Medford RM, Alexander RW. Oscillatory shear stress stimulates adhesion molecule expression in cultured human endothelium. Circ. Res. 1998; 82:53239. [PubMed: 9529157]

Chatzizisis YS, Coskun AU, Jonas M, Edelman ER, Feldman CL, Stone PH. Role of endothelial shear stress in the natural history of coronary atherosclerosis and vascular remodeling: molecular, cellular, and vascular behavior. J. Am. Coll. Cardiol. 2007; 49:2379-93. [PubMed: 17599600]

Chen BP, Li YS, Zhao Y, Chen KD, Li S, et al. DNA microarray analysis of gene expression in endothelial cells in response to 24-h shear stress. Physiol. Genomics. 2001; 7:55-63. [PubMed: 11595792]

Chien S. Mechanotransduction and endothelial cell homeostasis: the wisdom of the cell. Am. J. Physiol. Heart Circ. Physiol. 2007; 292:H1209-24. [PubMed: 17098825]

Chien S, Li S, Shyy YJ. Effects of mechanical forces on signal transduction and gene expression in endothelial cells. Hypertension. 1998; 31:162-69. [PubMed: 9453297]

Cho A, Mitchell L, Koopmans D, Langille BL. Effects of changes in blood flow rate on cell death and cell proliferation in carotid arteries of immature rabbits. Circ. Res. 1997; 81:328-37. [PubMed: 9285634]

Cukierman E, Pankov R, Stevens DR, Yamada KM. Taking cell-matrix adhesions to the third dimension. Science. 2001; 294:1708-12. [PubMed: 11721053]

Dai G, Kaazempur-Mofrad MR, Natarajan S, Zhang Y, Vaughn S, et al. Distinct endothelial phenotypes evoked by arterial waveforms derived from atherosclerosis-susceptible and -resistant regions of human vasculature. Proc. Natl. Acad. Sci. USA. 2004; 101:14871-76. [PubMed: 15466704]

Dancu MB, Berardi DE, Vanden Heuvel JP, Tarbell JM. Asynchronous shear stress and circumferential strain reduces endothelial NO synthase and cyclooxygenase- 2 but induces endothelin-1 gene expression in endothelial cells. Arterioscler. Thromb. Vasc. Biol. 2004; 24:2088-94. [PubMed: 15345505]

Dancu MB, Tarbell JM. Coronary endothelium expresses a pathologic gene pattern compared to aortic endothelium: correlation of asynchronous hemodynamics and pathology in vivo. Atherosclerosis. 2007; 192:9-14. [PubMed: 16806232]

Davies PF. Flow-mediated endothelial mechanotransduction. Physiol. Rev. 1995; 75:519-60. [PubMed: 7624393] 
Davies PF. Hemodynamic shear stress and the endothelium in cardiovascular pathophysiology. Nat. Clin. Pract. Cardiovasc. Med. 2009; 6:16-26. [PubMed: 19029993]

Davies PF, Tripathi SC. Mechanical stress mechanisms and the cell: an endothelial paradigm. Circ. Res. 1993; 72:239-45. [PubMed: 8418981]

Davis ME, Grumbach IM, Fukai T, Cutchins A, Harrison DG. Shear stress regulates endothelial nitricoxide synthase promoter activity through nuclear factor $\kappa B$ binding. J. Biol. Chem. 2004; 279:163-68. [PubMed: 14570928]

Dewey CF Jr, Bussolari SR, Gimbrone MA Jr, Davies PF. The dynamic response of vascular endothelial cells to fluid shear stress. J. Biomech. Eng. 1981; 103:177-85. [PubMed: 7278196]

Domanski M, Lloyd-Jones D, Fuster V, Grundy S. Can we dramatically reduce the incidence of coronary heart disease? Nat. Rev. Cardiol. 2011; 8:721-25. [PubMed: 22045046]

Dzau VJ, Braun-Dullaeus RC, Sedding DG. Vascular proliferation and atherosclerosis: new perspectives and therapeutic strategics. Nat. Med. 2002; 8:1249-56. [PubMed: 12411952]

Ekstrand J, Razuvaev A, Folkersen L, Roy J, Hedin U. Tissue factor pathway inhibitor-2 is induced by fluid shear stress in vascular smooth muscle cells and affects cell proliferation and survival. J. Vasc. Surg. 2010; 52:167-75. [PubMed: 20537494]

Fang Y, Shi C, Manduchi E, Civelek M, Davies PF. MicroRNA-10a regulation of pro-inflammatory phenotype in athero-susceptible endothelium in vivo and in vitro. Proc. Natl. Acad. Sci. USA. 2010; 107:13450-55. [PubMed: 20624982]

Faxon DP, Creager MA, Smith SC Jr, Pasternak RC, Olin JW, et al. Atherosclerotic Vascular Disease Conference: executive summary; Atherosclerotic Vascular Disease Conference proceeding for healthcare professionals from a special writing group of the American Heart Association. Circulation. 2004; 109:2595-604. [PubMed: 15173041]

Feintuch A, Ruengsakulrach P, Lin A, Zhang J, Zhou YQ, et al. Hemodynamics in the mouse aortic arch as assessed by MRI, ultrasound, and numerical modeling. Am.J. Physiol. Heart Circ. Physiol. 2007; 292:H884-92. [PubMed: 17012350]

Finn AV, Nakano M, Narula J, Kolodgie FD, Virmani R. Concept of vulnerable/unstable plaque. Arterioscler. Thromb. Vasc. Biol. 2010; 30:1282-92. [PubMed: 20554950]

Fitzgerald TN, Shepherd BR, Asada H, Teso D, Muto A, et al. Laminar shear stress stimulates vascular smooth muscle cell apoptosis via the Akt pathway. J. Cell Physiol. 2008; 216:389-95. [PubMed: 18247368]

Fleury ME, Boardman KC, Swartz MA. Autologous morphogen gradients by subtle interstitial flow and matrix interactions. Biophys. J. 2006; 91:113-21. [PubMed: 16603487]

Florian JA, Kosky JR, Ainslie K, Pang Z, Dull RO, Tarbell JM. Heparan sulfate proteoglycan is a mechanosensor on endothelial cells. Circ. Res. 2003; 93:e136-42. Presents the first clear demonstration of the role of the glycocalyx as a mechanotransducer on ECs. [PubMed: 14563712]

Fox JA, Hugh AF. Localization of atheroma: a theory based on boundary layer separation. Br. Heart. J. 1966; 28:388-99. [PubMed: 5936971]

Frangos JA, Eskin SG, Mclntire LV, Ives CL. Flow effects on prostacyclin production by cultured human endothelial cells. Science. 1985; 227:1477-79. This is the first srudy to show a direct effect of WSS on EC biochemical production. [PubMed: 3883488]

Friedman MR, Ehrlich LW. Numerical simulation of aortic bifurcation flows: the effect of flow divider curvature. J. Biomech. 1984; 17:881-88. [PubMed: 6520136]

Friedman MH, Hutchins GM, Bargeron CB, Deters OJ, Mark FF. Correlation between intimal thickness and fluid shear in human arteries. Atherosclerosis. 1981; 39:425-36. [PubMed: 7259822]

Fry DL. Certain histological and chemical responses of the vascular interface to acutely induced mechanical stress in the aorta of the dog. Circ. Res. 1969; 24:93-108. [PubMed: 5763742]

Garanich JS, Mathura RA, Shi ZD, Tarbell JM. Effects of fluid shear stress on adventitial fibroblast migration: implications for flow-mediated mechanisms of arterialization and intimal hyperplasia. Am. J. Physiol. Heart Circ. Physiol. 2007; 292:H3128-35. [PubMed: 17308005]

Garanich JS, Pahakis M, Tarbell JM. Shear stress inhibits smooth muscle cell migration via Nitricmediated downregulation of matrix metalloproteinase-2 activity. Am. J. Physiol. Heart Circ. Physiol. 2005; 288:H2244-52. [PubMed: 15637127] 
García-Cardeña G, Comander JI, Anderson KR, Blackman BR, Gimbrone MA Jr. Biomechanical activation of vascular endothelium as a determinant of its functional phenotype. Proc. Natl. Acad. Sci. USA. 2001a; 98:4478-85. Provides one of the earliest high-throughput gene expression studies of ECs exposed to shear stress in vitro. [PubMed: 11296290]

García-Cardeña G, Comander JI, Blackman BR, Anderson KR, Gimbrone MA Jr. Mechanosensitive endothelial gene expression profiles: scripts for the role of hemodynamics in atherogenesis? Ann. N. Y. Acad. Sci. 2001b; 947:1-6. [PubMed: 11795257]

Ge L, Dasi LP, Sotiropoulos F, Yoganathan AP. Characterization of hemodynamic forces induced by mechanical heart valves: Reynolds versus viscous stresses. Ann. Biomed. Eng. 2008; 36:276-97. [PubMed: 18049902]

Gimbrone MA Jr, Topper JN, Nagel T, Anderson KR, García-Cardeña G. Endothelial dysfunction, hemodynamic forces, and atherogenesis. Ann. N. Y. Acad. Sci. 2000; 902:230-39. Discussion. 902:239-40. [PubMed: 10865843]

Gomez D, Owens GK. Smooth muscle cell phenotypic switching in atherosclerosis. Cardiovasc. Res. 2012; 95:156-64. [PubMed: 22406749]

Gosgnach W, Challah M, Conlet F, Michel JB, Battle T. Shear stress induces angiotensin converting enzyme expression in cultured smooth muscle cells: possible involvement of bFGF. Cardiovasc. Res. 2000a; 45:486-92. [PubMed: 10728370]

Gosgnach W, Messika-Zeitoun D, Gonzalez W, Philipe M, Michel JB. Shear stress induces iNOS expression in cultured smooth muscle cells: role of oxidative stress. Am. J. Physiol. Cell. Physiol. 2000b; 279:C1880-88. [PubMed: 11078703]

Grabowski EF, Jaffe EA, Weksler BB. Prostacyclin production by cultured endothelial cell monolayers exposed to step increases in shear stress. J. Lab. Clin. Med. 1985; 105:36-43. [PubMed: 3918129]

Haga JH, Li YS, Chien S. Molecular basis of the effects of mechanical stretch on vascular smooth muscle cells. J. Biomech. 2007; 40:947-60. [PubMed: 16867303]

Haga M, Yamashita A, Paszkowiak J, Sumpio BE, Dardik A. Oscillatory shear stress increases smooth muscle cell proliferation and Akt phosphorylation. J. Vasc. Surg. 2003; 37:1277-84. [PubMed: 12764276]

Hajra L, Evans AI, Chen M, Hyduk SJ, Collins T, Cybulsky MI. The NF- $\kappa$ B signal transduction pathway in aortic endothelial cells is primed for activation in regions predisposed to atherosclerotic lesion formation. Proc. Natl. Acad. Sci. USA. 2000; 97:9052-57. [PubMed: 10922059]

He XH, Wu GF, Zhang Y, Chen XL, Zhang ZS, et al. Effect of chronic enhanced external counterpulastion on gene expression profiles of arterial endothelial cells of pigs fed with highcholesterol diet. Nan Fang Yi Ke Da Xue Xue Bao. 2008; 28:1195-97. In Chinese. [PubMed: 18676261]

Hendrickson RJ, Obda SS, Cahill PA, Yankah E, Sitzmann JV, Redmond EM. Ethanol inhibits basal and flow-induced vascular smooth muscle cell migration in vitro. J. Surg. Res. 1999; 84:64-70. [PubMed: 10334891]

Hishikawa K, Nakaki T, Marumo T, Hayashi M, Suzuki H, et al. Pressure promotes DNA synthesis in rat cultured vascular smooth muscle cells. J. Clin. Invest. 1994; 93:1975-80. [PubMed: 8182128]

Hsiai TK, Cho SK, Wong PK, Ing M, Salazar A, et al. Monocyte recruitment to endothelial cells in response to oscillatory shear stress. FASEB J. 2003; 17:1648-57. [PubMed: 12958171]

Hsieh HJ, Li NQ, Frangos JA. Shear-induced platelet-derived growth factor gene expression in human endothelial cells is mediated by protein kinase C. J. Cell Physiol. 1992; 150:552-58. [PubMed: 1537884]

Hsu S, Chu JS, Chen FF, Wang A, Li S. Effects of fluid shear stress on a distinct population of vascular smooth muscle cells. Cell Mol. Bioeng. 2011; 4:627-36. [PubMed: 22924082]

Janiczek RL, Blackman BR, Roy RJ, Meyer CH, Acton ST, Epstein FH. Three-dimensional phase contrast angiography of the mouse aortic arch using spiral MRI. Magn. Reson. Med. 2011; 66:1382-90. [PubMed: 21656547] 
Jeong SI, Kwon JH, Lim JI, Cho SW, Jung Y, et al. Mechano-active tissue engineering of vascular smooth muscle using pulsatile perfusion bioreactors and elastic PLCL scaffolds. Biomaterials. 2005; 26:1405-11. [PubMed: 15482828]

Jia X, Yang J, Song W, Li P, Wang X, et al. Involvement of large conductance $\mathrm{Ca}^{2+}$-activated $\mathrm{K}^{+}$ channel in laminar shear stress-induced inhibition of vascular smooth muscle cell proliferation. Pflugers Arch. 2013; 465:221-32. [PubMed: 23179380]

Joshi AK, Leask RL, Myers JG, Ojha M, Butany J, Ethier CR. Intimal thickness is not associated with wall shear stress patterns in the human right coronary artery. Arterioscler. Thromb. Vasc. Biol. 2004; 24:2408-13. [PubMed: 15472129]

Kim HJ, Vignon-Clementel IE, Coogan JS, Figueroa CA, Jansen KR, Taylor CA. Patient-specific modeling of blood flow and pressure in human coronary arteries. Ann. Biomed. Eng. 2010; 38:3195-209. [PubMed: 20559732]

Kohler TR, Jawien A. Flow affects development of intimal hyperplasia after arterial injury in rats. Arterioscler. Thromb. 1992; 12:963-71. [PubMed: 1637795]

Korenaga R, Ando J, Tsuhoi H, Yang W, Sakuma I, et al. Laminar flow stimulates ATP- and shear stress-dependent nitric oxide production in cultured bovine endothelial cells. Biochem. Biophys. Res. Commun. 1994; 198:213-19. [PubMed: 7507319]

Ku DN, Giddens DP, Zarins CK, Glagov S. Pulsatile flow and atherosclerosis in the human carotid bifurcation: positive correlation between plaque location and low oscillating shear stress. Arteriosclerosis. 1985; 5:293-302. Introduces the concept of oscillatory shear (OSI) as a localizing factor in antherosclerosis. [PubMed: 3994585]

Kuchan MJ, Frangos JA. Role of calcium and calmodulin in flow-induced nitric oxide production in endothelial cells. Am. J. Physiol. 1994; 266:C628-36. [PubMed: 8166225]

Li C, Xu Q. Mechanical stress-initiated signal transduction in vascular smooth muscle cells in vitro and in vivo. Cell Signal. 2007; 19:881-91. [PubMed: 17289345]

Li S, Lao J, Chen BP, Li YS, Zhao Y, et al. Genomic analysis of smooth muscle cells in 3-dimensional collagen matrix. FASEB J. 2003; 17:97-99. [PubMed: 12475912]

Lin K, Hsu PP, Chen BP, Yuan S, Usami S, et al. Molecular mechanism of endothelial growth arrest by laminar shear stress. Proc. Natl. Acad. Sci. USA. 2000; 97:9385-89. [PubMed: 10920209]

Makris GC, Nicolaides AN, Xu XY, Geroulakos G. Introduction to the biomechanics of carotid plaque pathogenesis and rupture: review of the clinical evidence. Br. J. Radiol. 2010; 83:729-35. [PubMed: 20647514]

Maldonado N, Kelly-Arnold A, Vengrenyuk Y, Laudier D, Fallon JT, et al. A mechanistic analysis of the role of microcalcifications in atherosclerotic plaque stability: potential implications for plaque rupture. Am. J. Physiol. Heart Circ. Physiol. 2012; 303:H619-28. [PubMed: 22777419]

McDonald, DA. Blood Flow in Arteries. Williams \& Wilkins; Baltimore: 1960.

Michel JB, Thaunat O, Houard X, Meilhac O, Caligiuri G, Nicoletti A. Topological determinants and consequences of adventitial responses to arterial wall injury. Arterioscler. Thromb. Vasc. Biol. 2007; 27:1259-68. [PubMed: 17395854]

Milnor, WR. Hemodynamics. Williams \& Wilkins; Baltimore: 1989.

Mitsumata M, Fishel RS, Nerem RM, Alexander RW, Berk BC. Fluid shear stress stimulates plateletderived growth factor expression in endothelial cells. Am. J. Physiol. 1993; 265:H3-8. [PubMed: 8342646]

Mo M, Eskin SG, Schilling WP. Flow-induced changes in $\mathrm{Ca}^{2+}$ signaling of vascular endothelial cells: effect of shear stress and ATP. Am. J. Physiol. 1991; 260:H1698-707. [PubMed: 2035689]

Nagel T, Resnick N, Atkinson WJ, Dewey CF Jr, Gimbrone MA Jr. Shear stress selectively upregulates intercellular adhesion molecule-1 expression in cultured human vascular endothelial cells. J. Clin. Invest. 1994; 94:885-91. [PubMed: 7518844]

Nam D, Ni CW, Rezvan A, Suo J, Budzyn K, et al. Partial carotid ligation is a model of acutely induced disturbed flow, leading to rapid endothelial dysfunction and atherosclerosis. Am. J. Physiol. Heart Circ. Physiol. 2009; 297:H1535-43. [PubMed: 19684185]

Nerem RM, Levesque MJ, Cornhill JF. Vascular endothelial morphology as an indicator of the pattern of blood flow. J. Biomech. Eng. 1981; 103:172-76. Demonstrates the relationship between EC morphology and flow (WSS) patterns in blood vessels. [PubMed: 7278195] 
Nguyen AT, Gomez D, Hell RU, Campbell JH, Clowes AW, et al. Smooth muscle cell plasticity: fact or fiction? Circ. Res. 2013; 112:17-22. [PubMed: 23093573]

Ni CW, Qiu H, Rezvao A, Kwon K, Nam D, et al. Discovery of novel mechanosensitive genes in vivo using mouse carotid artery endothelium exposed to disturbed flow. Blood. 2010a; 116:e66-73. [PubMed: 20551377]

Ni J, Waldman A, Khachigian LM. c-Jun regulates shear- and injury-inducible Egr-1 expression, vein graft stenosis after autologous end-to-side transplantation in rabbits, and intimal hyperplasia in human saphenous veins. J. Biol. Chem. 2010b; 285:4038-48. Presents the first high-throughput gene expression study of ECs exposed to shear stress in vivo. [PubMed: 19940138]

Noguchi N, Jo H. Redox going with vascular shear stress. Antioxid. Redox Signal. 2011; 15:1367-08. [PubMed: 21457103]

Oancca E, Wolfe Jf, Clapham DE. Functional TRPM7 channels accumulate at the plasma membrane in response to fluid flow. Circ. Res. 2006; 98:245-53. [PubMed: 16357306]

Osanai T, Akutsu N, Fujita N, Nakano T, Takahashi K, et al. Cross talk between prostacyclin and nitric oxide under shear in smooth muscle cell: role in monocyte adhesion. Am. J. Physiol. Heart Circ. Physiol. 2001; 281:H177-82. [PubMed: 11406483]

Owens GK, Kumar MS, Wamhoff BR. Molecular regulation of vascular smooth muscle cell differentiation in development and disease. Physiol. Rev. 2004; 84:767-801. [PubMed: 15269336]

Palumbo R, Gaetano C, Melillo G, Toschi E, Remuzzi A, Capogrossi MC. Shear stress downregulation of platelet-derived growth factor receptor- $\beta$ and matrix metalloprotease- 2 is associated with inhibition of smooth muscle cell invasion and migration. Circulation. 2000; 102:225-30. [PubMed: 10889135]

Papadaki M, McIntire LV, Eskin SG. Effects of shear stress on the growth kinetics of human aortic smooth muscle cells in vitro. Biotechnol. Bioeng. 1996; 50:555-61. [PubMed: 18627018]

Papadaki M, Ruef J, Nguyen KT, Li F, Patterson C, et al. Differential regulation of protease activated receptor-1 and tissue plasminogen activator expression by shear stress in vascular smooth muscle cells. Circ. Res. 1998a; 83:1027-34. [PubMed: 9815150]

Papadaki M, Tilton RG, Eskin SG, Mclntire LV. Nitric oxide production by cultured human aortic smooth muscle cells: stimulation by fluid flow. Am. J. Physiol. 1998b; 274:H616-26. [PubMed: 9486266]

Pedersen JA, Boschetti F, Swartz MA. Effects of extracellular fiber architecture on cell membrane shear stress in a 3D fibrous matrix. J. Biomech. 2007; 40:1484-92. [PubMed: 16987520]

Peiffer V, Rowland EM, Cremers SG, Weinberg PD, Sherwin SJ. Effect of aortic taper on patterns of blood flow and wall shear stress in rabbits: association with age. Atherosclerosis. 2012; 223:11421. [PubMed: 22658260]

Qiu Y, Tarbell JM. Numerical simulation of pulsatile flow in a compliant curved tube model of a coronary artery. J. Biomech. Eng. 2000; 122:77-85. [PubMed: 10790833]

Redmond EM, Cullen JP, Cahill PA, Sitzmann JV, Stefansson S, et al. Endothelial cells inhibit flowinduced smooth muscle cell migration: role of plasminogen activator inhibitor-1. Circulation. 2001; 103:597-603. [PubMed: 11157728]

Rensen SS, Doevendans PA, Van Eys GJ. Regulation and characteristics of vascular smooth muscle cell phenotypic diversity. Neth. Heart J. 2007; 15:100-8. [PubMed: 17612668]

Resnick N, Collins T, Atkinson W, Bonthron DT, Dewey CF Jr, Gimbrone MA Jr. Platelet-derived growth factor B chain promoter contains a cis-acting fluid shear-stress-responsive element. Proc. Nad. Acad. Sci. USA. 1993; 90:4591-95. Erratum. 90:7908 Describes the discovery of the shear stress-responsive element.

Rhoads DN, Fskin SG, McIntire LV. Fluid flow releases fibroblast growth factor-2 from human aortic smooth muscle cells. Arterioscler. Thromb. Vasc. Biol. 2000; 20:416-21. [PubMed: 10669638]

Rizzo V. Enhanced interstitial flow as a contributing factor in neointima formation: (shear) stressing vascular wall cell types other than the endothelium. Am. J. Physiol. Heart Circ. Physiol. 2009; 297:H1196-97. [PubMed: 19525374]

Sadeghi MR, Shirani E, Tafazzoli-Shadpour M, Samaee M. The effects of stenosis severity on the hemodynamic parameters: assessment of the correlation between stress phase angle and wall shear stress. J. Biomech. 2011; 44:2614-26. [PubMed: 21906742] 
Sartore S, Chiavegato A, Faggin E, Franch R, Puato M, et al. Contribution of adventitial fibroblasts to neointima formation and vascular remodeling: from innocent bystander to active participant. Cin. Res. 2001; 89:1111-21.

Schena M, Shalon D, Davis RW, Brown PO. Quantitative monitoring of gene expression patterns with a complementary DNA microarray. Science. 1995; 270:467-70. [PubMed: 7569999]

Schwartz MA. Integrins and extracellular matrix in mechanotransduction. Cold Spring Harb. Perspect. Biol. 2010; 2:a005066. [PubMed: 21084386]

Sharefkin JB, Diamond SL, Eskin SG, McIntire LV, Dieffenbach CW. Fluid flow decreases preproendothelin mRNA levels and suppresses endothelin-1 peptide release in cultured human endothelial cells. J. Vasc. Surg. 1991; 14:1-9. [PubMed: 2061949]

Sharma R, Yellowley CE, Civelek M, Ainslie K, Hodgson L, et al. Intracellular calcium changes in rat aortic smooth muscle cells in response to fluid flow. Ann. Biomed. Eng. 2002; 30:371-78. [PubMed: 12051621]

Shen J, Luscinskas FW, Connolly A, Dewey CF Jr, Gimbrone MA Jr. Fluid shear stress modulates cytosolic free calcium in vascular endothelial cells. Am. J. Phiysiol. 1992; 262:C384-90.

Shi Y, O’Brien JE, Fard A, Mannion JD, Wang D, Zalewski A. Adventitial myofibroblasts contribute to neointimal formation in injured porcine coronary arteries. Circulation. 1996; 94:1655-64. [PubMed: 8840858]

Shi ZD, Abraham G, Tarbell JM. Shear stress modulation of smooth muscle cell marker genes in 2-D and 3-D depends on mechanotransducrion by heparan sulfate proteoglycans and ERK1/2. PLoS One. 2010a; 5:e12196. [PubMed: 20808940]

Shi ZD, Ji XY, Berardi DE, Qazi H, Tarbell JM. Interstitial flow induces MMP-1 expression and vascular SMC migration in collagen 1 gels via an ERK1/2-dependent and c-Jun-mediated mechanism. Am. J. Physiol. Heart Circ. Physiol. 2010b; 298:H127-35. [PubMed: 19880665]

Shi ZD, Ji XY, Qazi H, Tarbel JM. Interstitial flow promotes vascular fibroblast, myofibroblast, and smooth muscle cell motility in 3-D collagen 1 via upregulation of MMP-1. Am. J. Physiol. Heart Cm. Physiol. 2009; 297:H1225-34.

Shi ZD, Tarbell JM. Fluid flow mechanotransduction in vascular mooth muscle cells and fibroblasts. Ann. Biomed. Eng. 2011; 39:1608-19. [PubMed: 21479754]

Shi ZD, Wang H, Tarbell JM. Heparan sulfate proteoglycans mediate intersticial flow mechanotransduction regulating MMP-B expression and cell motility via FAK-ERK in 3D collagen. PLoS One. 2011; 6:e15956. [PubMed: 21246051]

Shou Y, Jan KM, Rumschitzki DS. Transport in rat vessel walls. I. Hydraulic conductivities of the aorta, pulmonary artery, and inferior vena cava with intact and denuded endothelia. Am. J. Physiol. Heart Circ. Physiol. 2006; 291:H2758-71. [PubMed: 16731638]

Shyy YJ, Hsieh HJ, Usami S, Chien S. Fluid shear stress induces a biphasic response of human monocyte chemotactic protein 1 gene expression in vascular endothelium. Proc. Ntnl. Acad. Sci. USA. 1994; 91:4678-82.

Stegemann JP, Hong H, Nerem RM. Mechanical, biochemical, and extracellular matrix effects on vascular smooth muscle cell phenotype. J. Appl. Physiol. 2005; 98:2321-27. [PubMed: 15894540]

Stenmark KR, Davie N, Frid M, Gerasimovskaya E, Da M. Role of the adventitia in pulmonary vascular remodeling. Physiology. 2006; 21:134-45. [PubMed: 16565479]

Sterpetti AV, Cucina A, D’ Angelo LS, Cardillo B, Cavallaro A. Shear stress modulates the proliferation rate, protein synthesis, and mitogenic activity of arterial smooth muscle cells. Surgery. 1993; 113:691-99. [PubMed: 8506528]

Sterpetti AV, Cucina A, Fragale A, Lepidi S, Cavallaro A, Santoro-D'Angelo L. Shear stress influences the release of platelet derived growth factor and basic fibroblast growth factor by arterial smooth muscle cells. Eur J. Vasc. Surg. 1994; 8:138-42. [PubMed: 8181605]

Tada S, Dong C, Tarbell JM. Effect of the stress phase angle on the strain energy density of the endothelial plasma membrane. Biophys. J. 2007; 93:3026-33. [PubMed: 17660317]

Tada S, Tarbell JM. A computational study of flow in a compliant carotid bifurcation-stress phase angle correlation with shear stress. Ann. Biomed. Eng. 2005; 33:1202-12. [PubMed: 16133927] 
Tang Z, Wang A, Yuan F, Yan Z, Liu B, et al. Differenciation of multipotent vascular stem cells contributes to vascular diseases. Nat. Commun. 2012; 3:875. [PubMed: 22673902]

Tarbell JM. Mass transport in arteries and the localization of atherosclerosis. Annu. Rev. Biomed. Eng. 2003; 5:79-118. [PubMed: 12651738]

Tarbell JM. Shear stress and the endothelial transport barrier. Cardiovasc. Res. 2010; 87:320-30. [PubMed: 20543206]

Tarbell JM, Ebong EE. The endothelial glycocalyx: a mechano-sensor and -transduces. Sci. Signal. 2008; 1 pt8.

Tarbell JM, Shi ZD. Effect of the glycocalyx layer on transmission of interstitial flow shear stress to embedded cells. Biomecb. Model. Mechanobiol. 2013; 12:111-21. Theoretical modelling shows that interstitial flow-imposed solid shear stress transmitted through the glycocalyx layer on a cell embedded in a 3D ECM could be of the order of $20 \mathrm{dyn} / \mathrm{cm}^{2}$, similar to that experienced by Ecs.

Topper JN, Cai J, Falb D, Gimbrone MA Jr. Identification of vascular endothelial genes differentially responsive to fluid mechanical stimuli: Cyclooxygenase-2, manganese superoxide dismutase, and endothelial cell nitric oxide synthase are selectively up-regulated by steady laminar shear stress. Proc. Natl. Acad. Sci. USA. 1996; 93:10417-22. [PubMed: 8816815]

Torii R, Wood NB, Hadjiloizou N, Dowsey AW, Wright AR, et al. Stress phase angle depicts differences in coronary artery hemodynamics due to changes in flow and geometry after percutaneous coronary intervention. Am. J. Physiol. Heart Circ. Physiol. 2009; 296:H765-76. [PubMed: 19151251]

Tzima E, Irani-Tehrani M, Kiosses WB, Dejana E, Schultt DA, et al. A mechanosensory complex that mediates the endothelial cell response to fluid shear stress. Nature. 2005; 437:426-31. Presents the discovery of a mechanosensory complex upstream of integrins that transduces shear stresson ECs. [PubMed: 16163360]

Ucha H, Kawakami M, Yaginuma T. Shear stress as an inhibitor of vascular smooth muscle cell proliferation: role of transforming growth factor- $\beta 1$ and tissue-type plasminogen activator. Arterioscler. Thromb. Vasc. Biol. 1997; 17:1512-16. [PubMed: 9301628]

Uhl M, Mellert K, Striegl B, Deibler M, Lamla M, et al. Cyclic stretch increases splicing noise rate in cultured human fibroblasts. BMC Res. Notes. 2011; 4:470. [PubMed: 22040907]

Vasava P, Jalali P, Dabagh M, Kolari PJ. Finite element modelling of pulsatile blood flow in idealized model of human aortic arch: study of hypotension and hypertension. Comput. Math. Methods Med. 2012; 2012:861837. [PubMed: 22400055]

Vincent PE, Plata AM, Hunt AA, Weinherg PD, Sherwin SJ. Blood flow in the rabbit aortic arch and descending thoracic aorta. J. R. Soc. Interface. 2011; 8:1708-19. [PubMed: 21593030]

Wagner CT, Durante W, Christodoulides N, Hellums JD, Schafer AT. Hemodynamic forces induce the expression of heme oxygenasc in cultured vascular smooth muscle cells. J. Clin. Invest. 1997; 100:589-96. [PubMed: 9239406]

Wang DM, Tarbell JM. Modeling interstitial flow in an artery wall allows estimation of wall shear stress on smooth muscle cells. J. Biomech. Eng. 1995; 117:358-63. [PubMed: 8618390]

Wang H, Yan S, Chai H, Riha GM, Li M, et al. Shear stress induces endothelial transdifferentiation from mouse smooth muscle cells. Biochem. Biophys. Res. Commun. 2006; 346:860-65. [PubMed: 16793021]

Wang S, Tarbell JM. Effect of fluid flow on smooth muscle cells in a 3-dimensional collagen gel model. Arterioscler. Thromb. Vasc. Biol. 2000; 20:2220-25. This is the first study to investigate effects of interstitial flow on SMCs in 3D in vitro model. [PubMed: 11031207]

Weinbaum S, Tarbell JM, Damiano ER. The structure and function of the endothelial glycocalyx layer. Annu. Rev. Biomed. Eng. 2007; 9:121-67. [PubMed: 17373886]

Weinbaum S, Tzegliai C, Ganatos P, Pfeffer R, Chien S. Effect of cell turnover and leaky junctions on arterial macromolecular transport. Am. J. Physiol. 1985; 248:H945-60. [PubMed: 4003572]

White GE, Gimbrone MA Jr, Fujiwara K. Factors influencing the expression of stress fibers in vascular endothelial cells in situ. J. Cell Biol. 1983; 97:416-24. [PubMed: 6684121]

Winter DC, Nerem RM. Turbulence in pulsatilc flows. Ann. Biomed. Eng. 1984; 12:357-69. [PubMed: 6532271] 
Wong AJ, Pollard TD, Herman IM. Actin filament stress fibers in vascular endothelial cells in vivo. Science. 1983; 219:867-69. [PubMed: 6681677]

Zarins CK, Giddens DP, Bharadvaj BK, Sottiurai VS, Mabon RF, Glagov S. Carotid bifurcation atherosclerosis: quantitative correlation of plaque localization with flow velocity profiles and wall shear stress. Circ. Res. 1983; 53:502-14. [PubMed: 6627609]

Zeng Y, Ebong EE, Fu BM, Tarbell JM. The structural stability of the endothelial glycocalyx after enzymatic removal of glycosaminoglycans. PLoS One. 2012; 7:e43168. [PubMed: 22905223] 


\section{SUMMARY POINTS}

1. Fluid mechanical factors influence the localization of atherosclerosis at discrete sites in the circulation.

2. Low mean WSS and high OSI are currently believed to be the main fluid mechanical localizing factors in atherosclerosis.

3. Stable, unidirectional shear stress supports a healthy, anti-inllammatory state, whereas disturbed flow (low mean WSS and high OSI) induces an inflammatory, thrombotic state. Each shear stress environment induces a distinct gene expression profile.

4. The activation of shear-responsive genes is dependent on the ability of ECs to sense their mechanical environment and initiate intracellular signaling events.

5. SSREs are common elements of gene promoters that are regulated by a single shear-controlled transcription factor. SSREs enable the coregulation of shearresponsive genes.

6. High-through put genome-wide analysis technitrues have enabled researchers to discover key shear-responsive genes and regulatory pathways that have functional consequences in the development of atherosclerosis.

7. Vascular SMCs play a key role in vascular remodeling and disease. Modeling studies have shown that, upon vascular injury, SMCs experience elevated transmural interstitial flow and shear stress similar to the level experienced by ECs.

8. Interstitial flow and shear stress modulate SMC gene expression, regulating cell biology and function including secretion, proliferation, phenotypic switching, and migration.

9. SMC surface glycocalyx, integrins, and ERK1/2 signaling pathways likely play key roles in shear tress mechanotransduction regulating SMC function. 


\section{FUTURE ISSUES}

1. It is important to determine how solid mechanical forces (e.g., CS) modulate the influence of fluid mechanical fores (WSS) on EC gene expression. This will require detailed studies of combined fluid mechanics and solid mechanics in arteries.

2. Teasing out the molecular events involved in mechanotransduction will be key to understanding how specific intracellular signaling pathways become activated/deactivated in response to flow patterns.

3. The detennination of key master regulatory genes that control proinflammatory and prothrombotic pathways will provide insight for novel therapeutic target.

4. SMC culture models that faith fully mimic the complex $3 \mathrm{D}$ in vivo environment and in vivo models with controlled interstitial flow need to he developed to study SMC responses. 


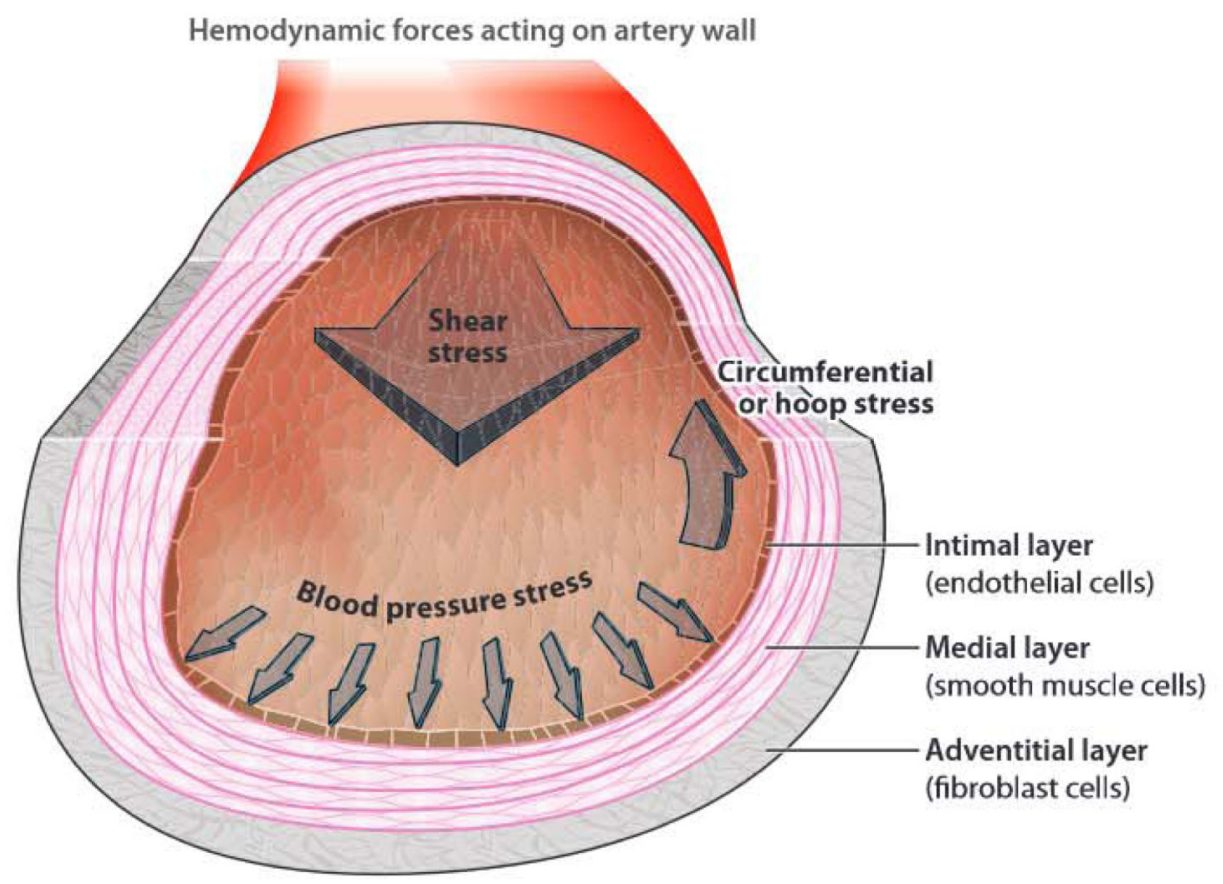

Figure 1.

The arterial wall consists of three layers: the intima, the innermost layer that is in contact with blood, which consists of a lining layer of endothelial cells and a thin basement matrix for endothelial attachment; the media, which contains layers of smooth muscle cells that are separated by elastic lamina; and the adventitia, the outermost layer, which contains fibroblasts embedded in loose connective tissue. The forces (stresses) acting on the arterial wall are the normal stress of blood pressure that is balanced by the circumferential stress in the wall and the fluid shear stress that is tangential to the endothelial cell surface. 


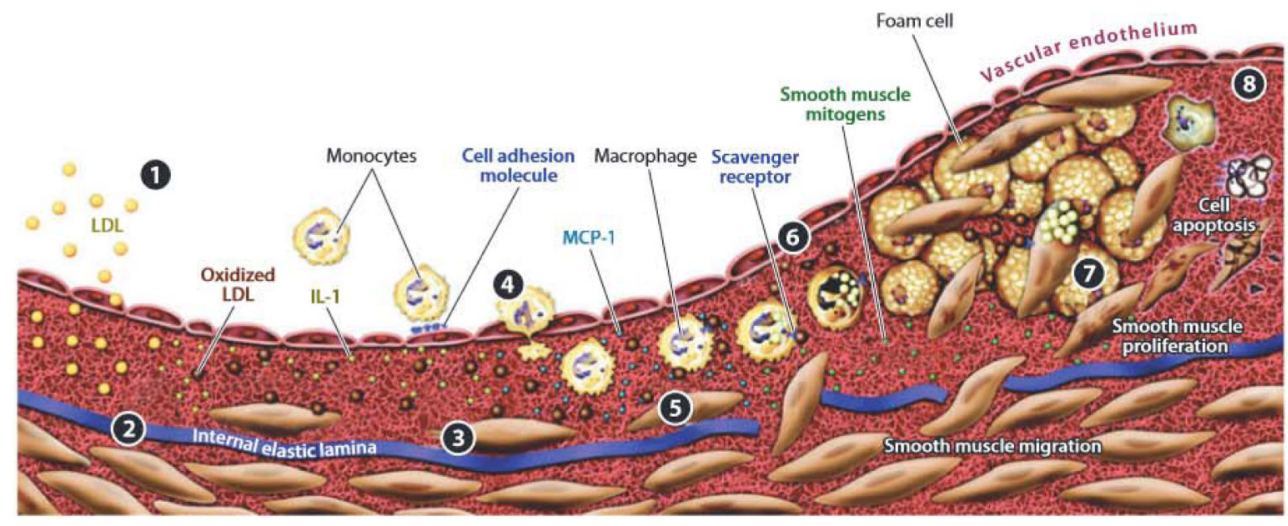

Figure 2.

The eight stages of development of an atherosclerotic plaque. First LDL moves into the subendothelium and is oxidized by Macrophages and smooth muscle cells (steps 1 and 2). The release of growth factors and cytokines attracts additional monocytes (steps 3 and 4). Foam cell accumulation and smooth muscle cell proliferation result in the growth of the plaque (steps 6-8). Figure adapted with permission from Faxon et al. (2004). 


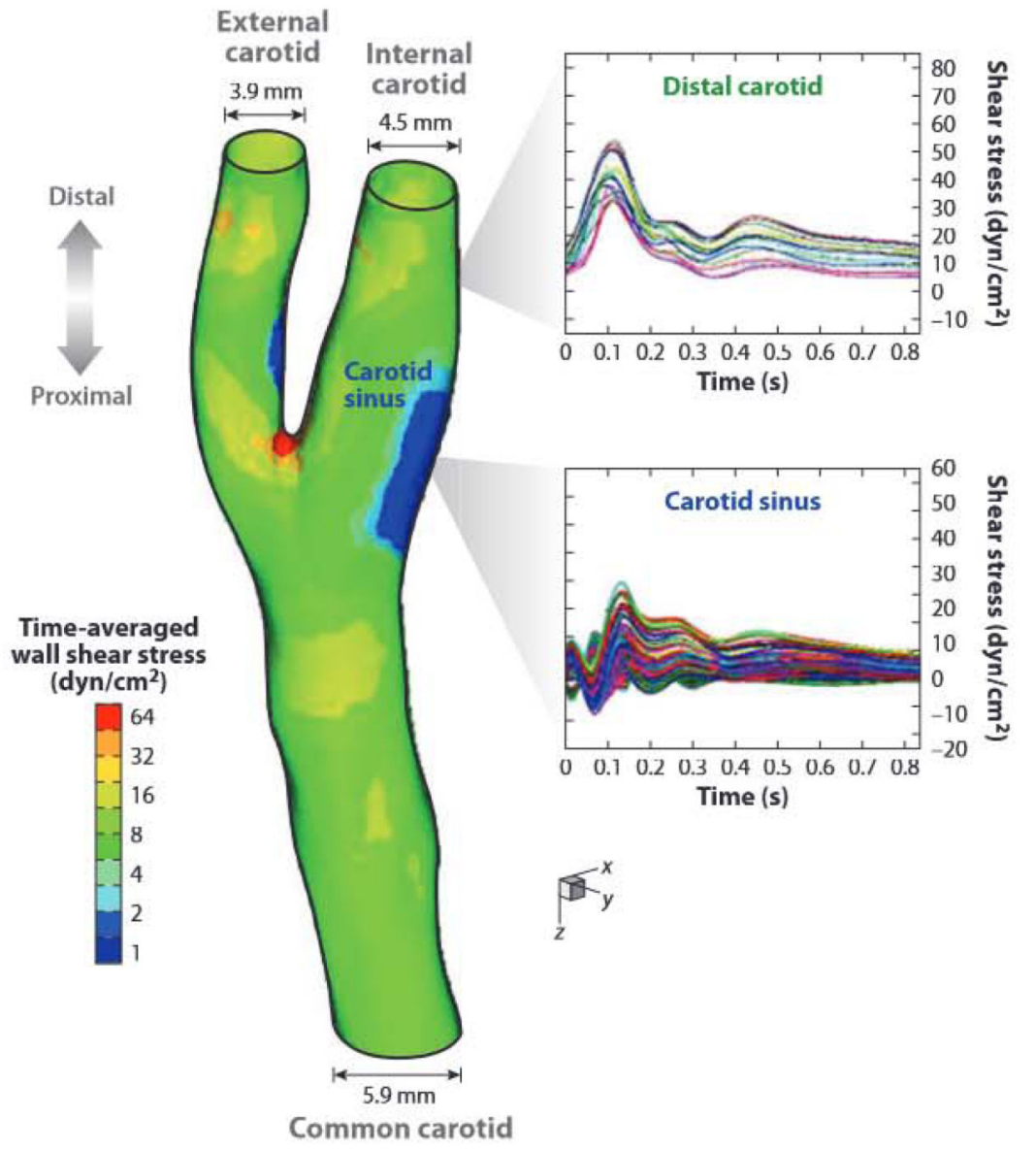

Figure 3.

Hemodynamics in the human carotid bifurcation display a wide range of wall shear stress (WSS) characteristics. (Left.) The carotid anatomy of a normal human subject (27-year-old male) was reconstructed from noninvasive magnetic resonance imaging measurements. The color-coded map shown in this carotid model displays the time-averaged WSS magnitude at different points along the vascular wall. Clearly the carotid sinus is a region of very low mean WSS and also a site of atherosclerotic plaque development. Regions in the distal internal carotid artery and carotid sinus were selected, and the time-dependent WSS values along the mean flow direction from multiple individual points within each region were plotted for one cardiat cycle (right). For the carotid sinus, the peak WSS clearly is lower than in the distal carotid, and the minimum WSS in the carotid is actually negative, indicating a time interval of WSS reversal (retrograde flow) that is not apparent in the distal carotid. Figure adapted with permission from Dai et al. (2004). 
a

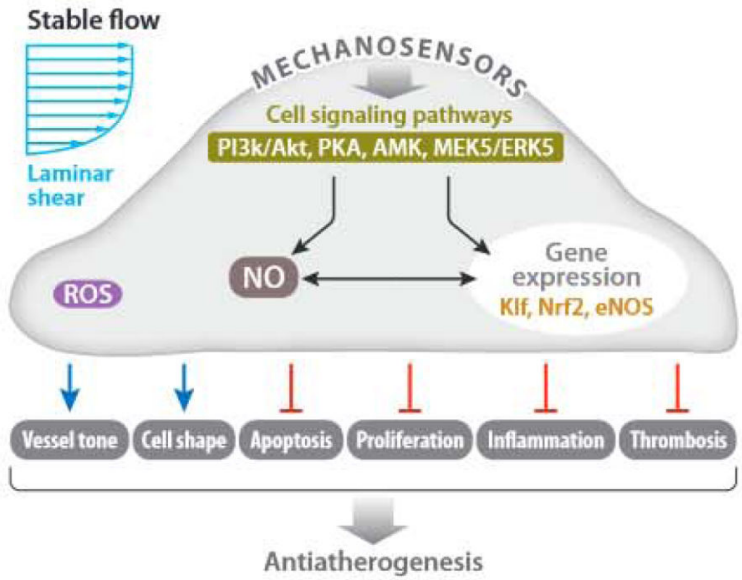

b

Disturbed flow

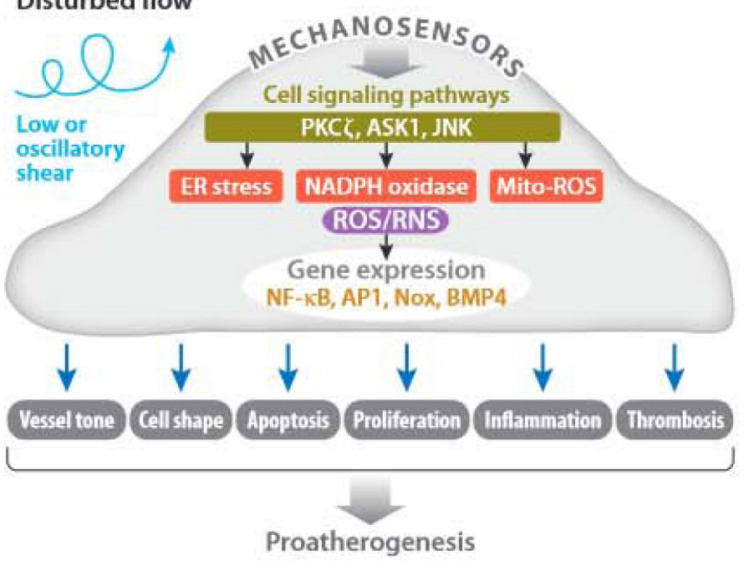

Figure 4.

Mechanotransduction signaling pathways in endothelial cells in response to $(a)$ laminar or (b) oscillatory shear stress stimuli. Laminar shear stress stabilizes a healthy, antiinflammatory state in endothelial cells that results in cytoskeletal remodeling and endothelial cell alignment in the direction of flow, as well as increased nitric oxide production and suppresion of inflammatory cell adhesion molecules. Conversely, disturbed flow or oscillatory shear stress induces an inflammatory and thrombotic state characterized by high expression of cell adhesion molecules and production of inflammatory cytokines, high oxidative stress, lack of cell alignment with flow, and a leaky endothelial cell barrier that allows infiltration of smooth muscle cells and immunomodulatory cell types (Noguchi \& Jo 2011). 


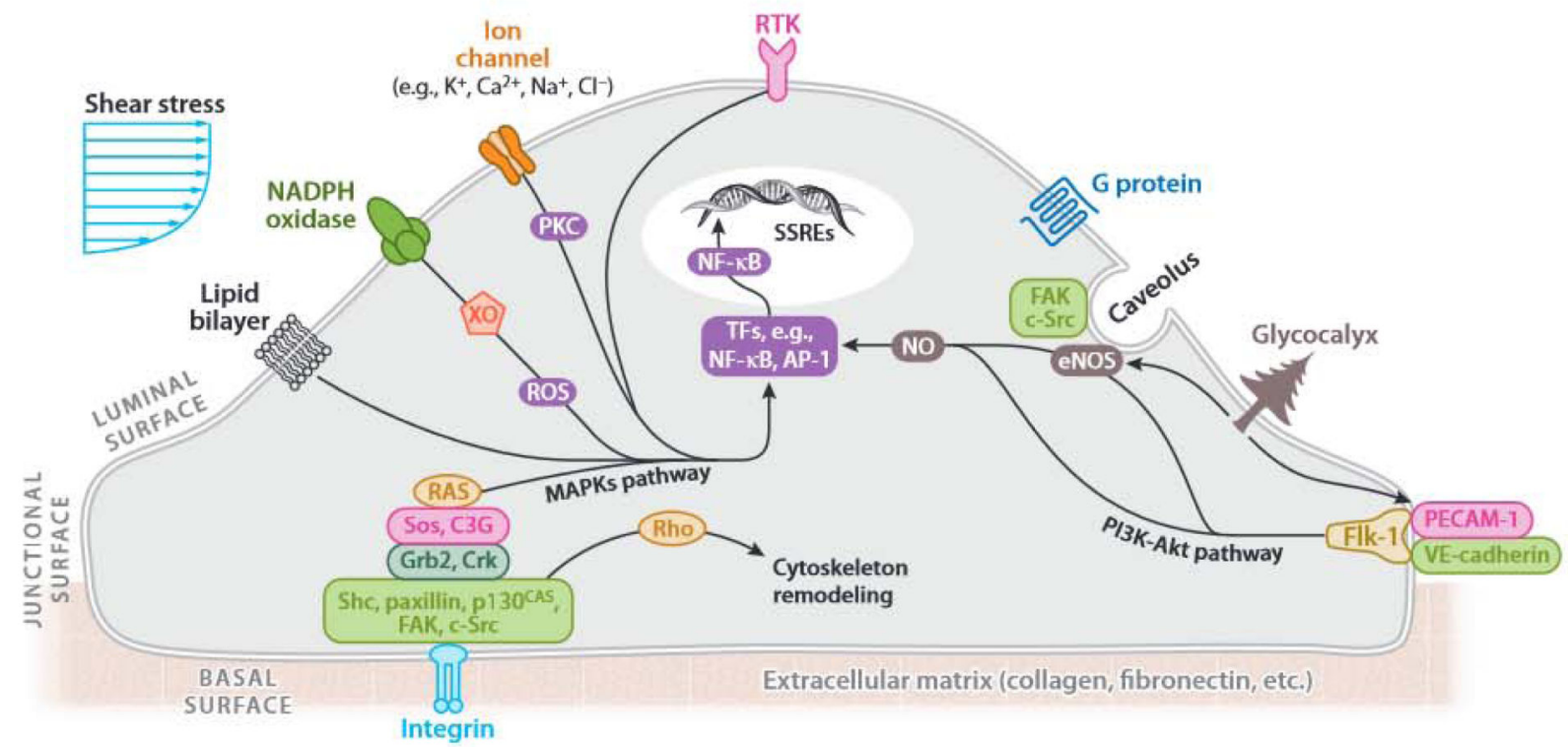

Figure 5.

Mechanosensory pathways utilizing surface mechanoreceptors [e.g., ion channels $\left(\mathrm{K}^{+}, \mathrm{Ca}^{+}\right.$, $\mathrm{Na}^{+}, \mathrm{Cl}^{-}$), receptor tyrosine kinases, $\mathrm{G}$ protein coupled receptors), cell-cell and cell-matrix adhesion complexes (e.g., PECAM-1/VE-cadherin/VEGFR2 complex and focal adhesion kinases), the glycocalyx, and cytoskeletal elements that transduce signals and result in downstream signal amplification via master regulators such as kinase cascades and transcription factor networks. These signaling events alter the endothelial cell phenotype and behavior in response to extracellular biomechanical stimuli. Figure adapted with permission from Chatzizisis et al. (2007). 


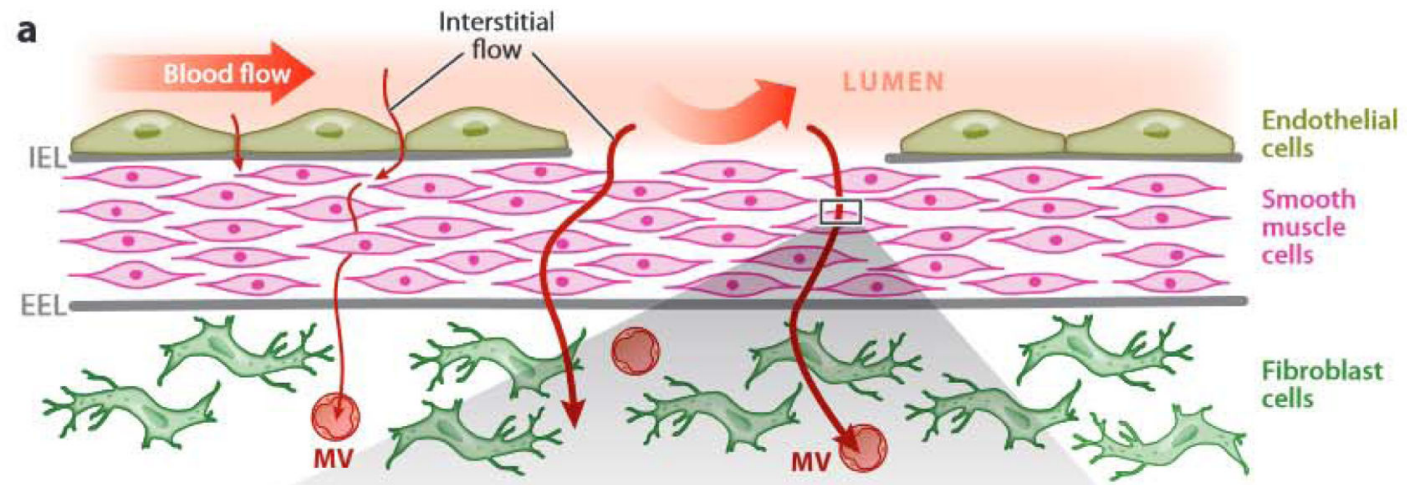

b

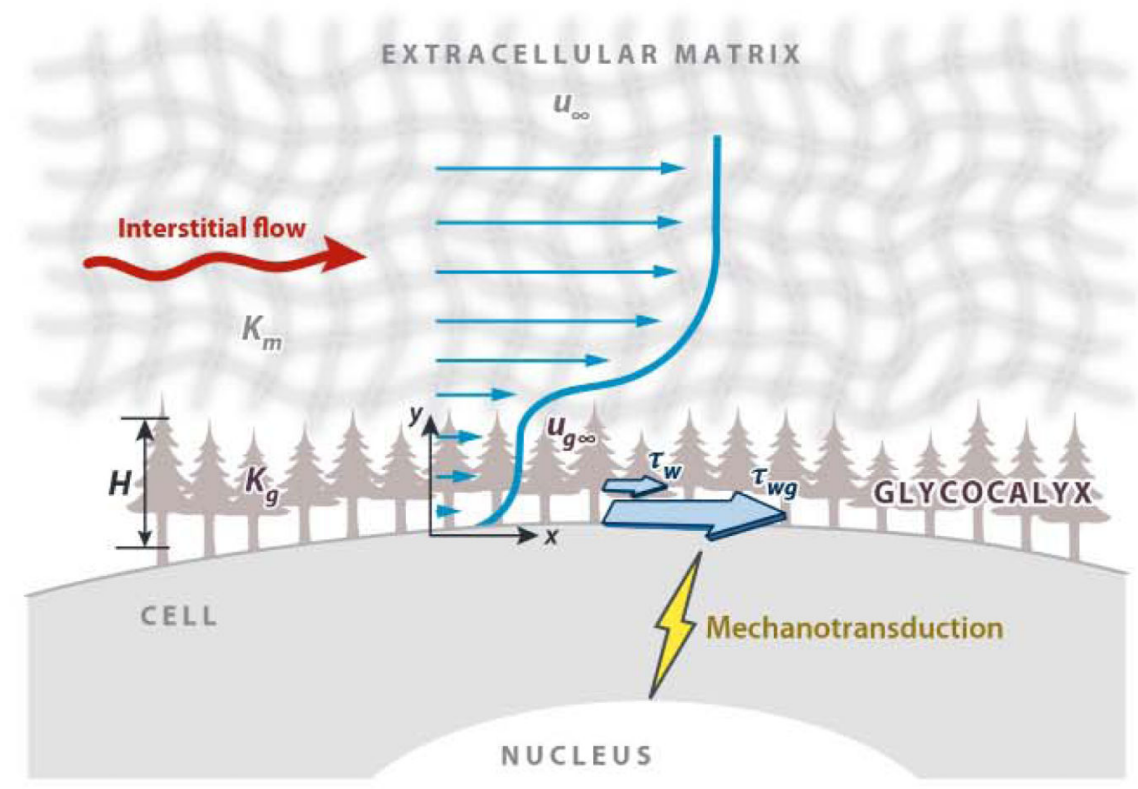

Figure 6.

Interstitial flow shear stress and vascular injury. (a) Vascular smooth muscle cells (SMCs) and fibroblasts (FBs) in the intact artery are not exposed to luminal blood flow shear stress that normally is experienced by endothelial cells but are exposed to a very low physiological transmural interstitial flow (top left). The interstitial flow is driven by the pressure diffrentials between the arterial lumen and the adventital microvessels (MVs) (i.e., vasa vasorum and lymphatics) or the surrounding tissue. After endothelial denudation, the superficial SMCs may be exposed to the blood flow, and the medial SMCs and adventitial FBs are exposed to elevated interstitial fluid flow. (b) The glycocalyx can mediate interstitial flow mechanotransduction by sensing interstitial flow and transmitting solid stresses $\left(\tau_{w g}\right)$ to the cell membrane that are 10-100-fold higher than the fluid shear stress $\left(\tau_{w}\right)\left|\tau_{w g} / \tau_{w} \approx H / \sqrt{\left(K_{g}\right)}\right| H$ is the glycocalyx thickness $K^{g}$ the Darcy permeability of the glycocalyx, $K_{m}$ the Darcy permeability of the surrounding extracellular matrix, $\mu^{\infty}$ the superficial velocity far from the surface, and $\mu^{g} \infty$ the velocity in the glycocalyx layer far from the cell surface. Readers are referred to Wang \& Tarbell (1995) and Tarbell \& Shi (2013) for detailed modeling. Figure adapted with permission from Shi \& Tarbell (2011) 
and Tarbell \& Shi (2013). Abbreviations: EEL, external elastc lamina; IEL, internal elastic lamina. 